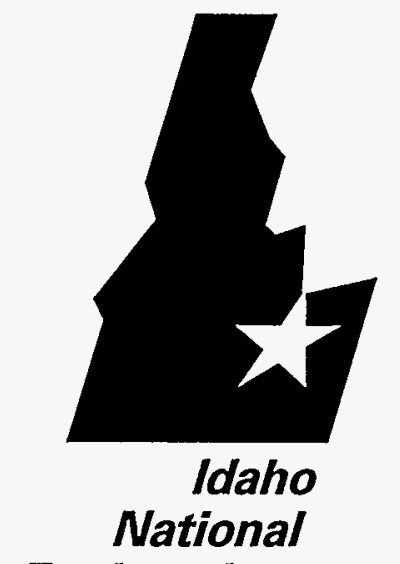

Engineering Laboratory
INEL-96/0246

July 1996

Radioactive Liquid Waste Generation Goals at the ICPP

J. L. Tripp

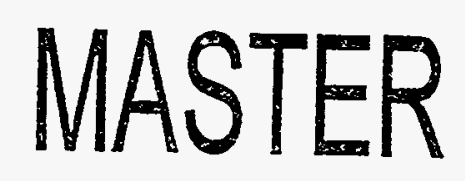

DISTRISUTION OF THUS DOCUMENT IS UALMMTED

$\beta B$

Ftlockheed

Idaho Technologies Company 


\section{DISCLAIMER}

This report was prepared as an account of work sponsored by an agency of the United States Government. Neither the United States Government nor any agency thereof, nor any of their employees, makes any warranty, express or implied, or assumes any legal liability or responsibility for the accuracy, completeness, or usefulness of any information, apparatus, product, or process disclosed, or represents that its use would not infringe privately owned rights. Reference herein to any specific commercial product, process, or service by trade name, trademark, manufacturer, or otherwise does not necessarily constitute or imply its endorsement, recommendation, or favoring by the United States Government or any agency thereof. The views and opinions of authors expressed herein do not necessarily state or reflect those of the United States Government or any agency thereof. 


\title{
Radioactive Liquid Waste Generation. Goals at the ICPP
}

\author{
J. L. Tripp
}

Published July 1996

\section{Idaho National Engineering Laboratory High Level Waste Program Department Lockheed Martin Idaho Technologies Company Idaho Falls, Idaho 83415}




\section{CONTENTS}

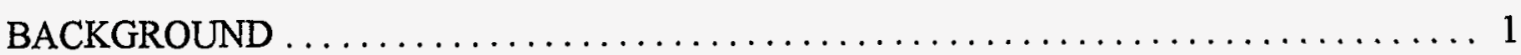

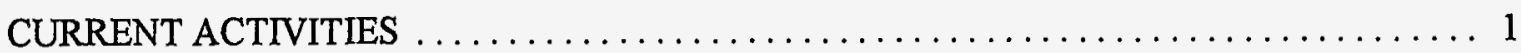

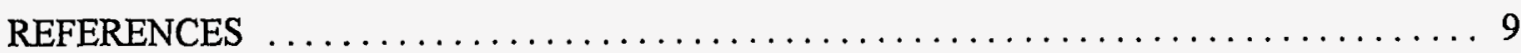

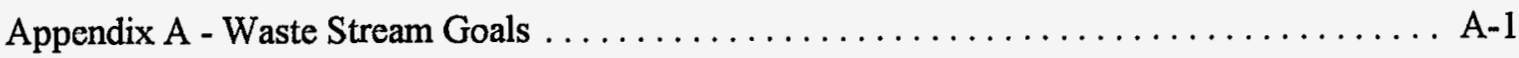

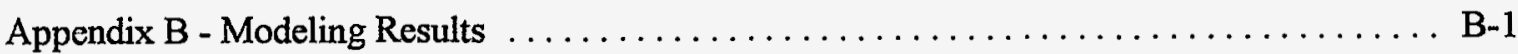

FIGURES

1. Changes in waste generation estimates for the period $1996-2012 \ldots \ldots \ldots \ldots \ldots \ldots$

2. Graph 1: Improvement options for NWCF through $2012 \ldots \ldots \ldots \ldots \ldots \ldots \ldots \ldots$

3. Waste generation program logic diagram $\ldots \ldots \ldots \ldots \ldots \ldots \ldots \ldots \ldots \ldots$

TABLES

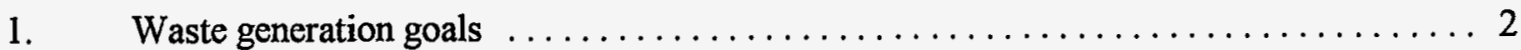




\section{DISCLAIMER}

Portions of this document may be illegible in electronic image products. Images are produced from the best available original document. 


\section{Radioactive Liquid Waste Generation Goals at the ICPP}

\section{BACKGROUND}

Processes operating at the ICPP generate hazardous radioactive liquid waste which is sent to the tank farm. These processes include NWCF, PEW evaporator, LET\&D, tank farm, and fuel storage operations as well as others. The recently signed Batt Settlement Agreement between the DOE, Navy and State of Idaho indicates that all waste in the tank farm must be calcined by the end of 2012 . Therefore, each gallon added to the tank farm is one more gallon which must be calcined prior to the 2012 date. Past projections of the future waste generation showed an extensive effort on waste reduction is required, as well as improved calcining rates, to reach the 2012 goal.

Baseline waste generation goals were first established in Appendix B of the ICPP Tank Farm Systems Analysis report in January of 1994 . $^{1}$ These estimates projected waste generation based on the best knowledge available at that time. These projections with a few adjustments have been used in the modeling conducted to date.

In May of 1994, the INEL Radioactive Liquid Waste Management Plan was issued. ${ }^{2}$ This report proposed an integrated plan to manage generation of radioactive liquid waste at the INEL based on a budgeting type approach. This report also recommended waste minimization goals established as annual targets or ceiling limits and incorporated into CPAF, Progress Tracking, or Total Quality processes including non-financial objectives and company performance indicators. Approval for all waste generation and additional approvals for waste generation over the fiscal year's goal was needed. This plan was never implemented.

\section{CURRENT ACTIVITIES}

The waste generation goals have been reviewed and updated and are shown in Table 1. Appendix A gives more details on these waste streams. The new goals were based on historical information taken from the monthly tank farm report, on previously forecast numbers, on projected projects and operations, on waste streams currently approved and on consultations with the subject matter experts in the various waste generation areas. A facilitated meeting was held to determine the new waste generation goals and best approach to reaching them. ${ }^{3}$ The participants in this meeting included operations, environmental, engineering and technology development personnel.

Waste streams were individually analyzed in this meeting and several adjustments made. Further adjustments were made after the meeting to reduce the risks associated with meeting the goals. Some of these risks include operation of the evaporators. It was indicated the evaporators will be operated more conservatively in the future because of a lack of money to replace parts and conduct repairs. Therefore, the reduction ratios on the waste streams were reduced to reflect this problem. It was also noted there are some operating limits on the PEW and HLLWE which effect the efficiency of the operation (7000 $\mathrm{gal} /$ day of feed to the PEW based on the RCRA permit). 
Table 1. Waste generation goals.

\begin{tabular}{|c|c|c|}
\hline Waste Stream & $\begin{array}{l}\text { Volume Generation and } \\
\text { Evap. Reduction }\end{array}$ & Comments and Concerns \\
\hline 1 -NWCF Bed Dissolutions & $\begin{array}{l}25,000 \text { gallons/dissolution. } \\
3 \text { dissolutions/run. } \\
\text { Direct to Tank Farm then } 2: 1 \text { HLLW } \\
\text { reduction. }\end{array}$ & $\begin{array}{l}\text { Assume } 1000 \text { gallons of bed dissolved, } \\
\text { which at a } 7: 1 \text { ratio is equivalent to } 7000 \\
\text { gallons of blended feed. Therefore } 56 \% \text { of } \\
\text { the } 12,500 \text { evaporated gallons is blended } \\
\text { feed and no additional ANN is needed to } \\
\text { calcine. }\end{array}$ \\
\hline $\begin{array}{c}2 \text { - NWCF Operations } \\
.\end{array}$ & $\begin{array}{l}3000 \text { gallons/month while operating } \\
\text { NWCF. } \\
\text { No evaporator reduction. }\end{array}$ & $\begin{array}{l}\text { Includes deep recycle of scrub, absorber } \\
\text { washer, etc. } \\
\text { Assume } 50 \% \text { is equivalent to blended feed } \\
\text { so no additional ANN is needed to calcine. }\end{array}$ \\
\hline 3 -NWCF Turnaround & $\begin{array}{l}70,000 \text { gallons of decon solutions for a } \\
12 \text { month turnaround. } \\
180,000 \text { gallons of decon solutions for a } \\
3 \text { or } 4 \text { year turnaround. } \\
40 \% \text { of each direct to Tank Farm then } \\
2: 1 \text { HLLWE reduction. } \\
60 \% \text { of each of PEW for } 20: 1 \text { reduction } \\
\text { then } 2: 1 \text { HLLWE reduction. }\end{array}$ & $\begin{array}{l}\text { Assumes no major vessel replacements. } \\
\text { Consists of nitric acid, dissolved calcine, } \\
\text { water, and various decon chemicals. }\end{array}$ \\
\hline 4 -PEWE Direct to Tank Farm & $\begin{array}{l}3000 \text { gallons/year. } \\
\text { 2:1 HLLWE reduction. }\end{array}$ & $\begin{array}{l}\text { This is acid or other solutions with high } \\
\text { chloride, organics, or other components } \\
\text { not allowed in the PEW. }\end{array}$ \\
\hline 5- 603 Removal & $\begin{array}{l}1.5 \text { million gallons of water. } \\
50,000 \text { gallons/month starting in FY-99 } \\
\text { until all processed. } \\
\text { 30:1 PEW reduction then } 2: 1 \text { FILLWE } \\
\text { reduction. }\end{array}$ & $\begin{array}{l}\text { May be able to achieve higher PEW } \\
\text { reduction without RCRA permit limit of } \\
7000 \text { gal feed/day and with adequate spare } \\
\text { parts for PEW maintenance. (Same in all } \\
\text { "water evap" cases.) }\end{array}$ \\
\hline $\begin{array}{l}\text { 6- ROVER Deactivation - } \\
\text { (CPP-640) }\end{array}$ & $\begin{array}{l}10,000 \text { gallons/yr for FY- } 98,-99 \text {, and - } \\
00 \text {. } \\
\text { 20:1 PEW reduction then 2:1 HLLWE } \\
\text { reduction. }\end{array}$ & $\begin{array}{l}\text { Consists of water, nitric acid and decon } \\
\text { solutions. }\end{array}$ \\
\hline 7 - CPP-601 Decontamination & $\begin{array}{l}3000 \text { gallons in FY- } 96 \text { for embedded line } \\
\text { project. } \\
\text { 20:1 PEW reduction then } 2: 1 \text { HLLWE } \\
\text { reduction. }\end{array}$ & $\begin{array}{l}\text { Consists of water, nitric acid and decon } \\
\text { solutions. } \\
\text { No further work in CPP- } 601 \text { is planned. }\end{array}$ \\
\hline 8 - Filter Leach & $\begin{array}{l}115 \text { filters/yr processed with three } 60 \text { gal } \\
3 \mathrm{M} \text { acid washes and two } 60 \text { gal water } \\
\text { rinses per batch. } \\
\text { 10:1 PEW reduction then } 2: 1 \text { HLLWE } \\
\text { reduction. } \\
\text { Currently have } 256 \text { filters in NWCF } \\
\text { storage, } 147 \text { in FDP ( } 6 \text { filters/batch), and } \\
34 \text { in RWMC. }\end{array}$ & $\begin{array}{l}115 \text { filters/yr is maximum allowed in Part } \\
\mathrm{B} \text { permit. } \\
\text { There is a possibility this could be higher if } \\
\text { non-ICPP filters are processed. } \\
\text { This waste stream is currently mixed with } \\
\text { other waste from NWCF decontamination } \\
\text { area. }\end{array}$ \\
\hline $\begin{array}{l}\text { 9- Tank Farm Sumps to Tank } \\
\text { Farm }\end{array}$ & $\begin{array}{l}100 \text { gallons/year. } \\
\text { No further reduction. }\end{array}$ & \\
\hline 10 - LET\&D to Tank Farm & $\begin{array}{l}3500 \text { gallons of } 13 \mathrm{M} \text { nitric acid in FY- } \\
96 . \\
\text { No further reduction. }\end{array}$ & $\begin{array}{l}\text { Assumes acid recycle tank will be in } \\
\text { service starting FY-97. Then all acid will } \\
\text { be reused in processing or } \\
\text { decontamination operations. }\end{array}$ \\
\hline
\end{tabular}


Table 1. (Continued)

\begin{tabular}{|c|c|c|}
\hline Waste Stream & $\begin{array}{l}\text { Volume Generation and } \\
\text { Evap. Reduction } \\
\end{array}$ & Comments and Concerns \\
\hline 11 - Tank Farm Line Flushes & $\begin{array}{l}1000 \mathrm{gal} / \mathrm{yr} \text { to tank farm. } \\
\text { No further reduction. }\end{array}$ & $\begin{array}{l}\text { This covers possible upgrades to } 6 \text { valve } \\
\text { boxes and other maintenance work. }\end{array}$ \\
\hline 12 - FSA Deactivation & $\begin{array}{l}3.2 \text { million gallons of water starting in } \\
\text { FY- } 2008 \text {. } \\
50,000 \text { gallons/mo to PEW. } \\
\text { 30:1 PEW reduction then } 2: 1 \text { HLLWE } \\
\text { reduction. }\end{array}$ & $\begin{array}{l}\text { This is a new waste stream anticipated in } \\
\text { this time frame. }\end{array}$ \\
\hline \multicolumn{3}{|l|}{13 - PEW Bottoms } \\
\hline A. NWCF Operations & $\begin{array}{l}2500 \text { gallons/mo during NWCF } \\
\text { operations. } \\
20: 1 \text { PEW reduction then 2:1 HLLWE } \\
\text { reduction. }\end{array}$ & $\begin{array}{l}\text { Floor drains, etc. } \\
\text { This waste stream during non-operating } \\
\text { periods is covered under NWCF } \\
\text { tumaround waste streams. }\end{array}$ \\
\hline B. FAST FSA & $\begin{array}{l}25,000 \mathrm{gal} / \mathrm{yr} \text { until deactivation in } 2008 \text {. } \\
30: 1 \mathrm{PEW} \text { reduction then } 2: 1 \text { HLLWE } \\
\text { reduction. }\end{array}$ & $\begin{array}{l}\text { From filter backwashes, cask washdown, } \\
\text { etc. }\end{array}$ \\
\hline C. FAST FDP & $\begin{array}{l}3000 \mathrm{gal} / \mathrm{yr} . \\
30: 1 \mathrm{PEW} \text { reduction then 2:1 HILWE } \\
\text { reduction. }\end{array}$ & $\begin{array}{l}\text { From safety shower testing, mop downs, } \\
\text { etc. }\end{array}$ \\
\hline D. Cell Floor Drains & $\begin{array}{l}36,000 \mathrm{gal} / \mathrm{yr} \text {. } \\
\text { 20:1 PEW reduction then 2:1 HLLWE } \\
\text { reduction. }\end{array}$ & $\begin{array}{l}\text { This is CPP- } 601 \text { deep tanks, mostly } \\
\text { analytical waste, therefore could be high } \\
\text { chloride. }\end{array}$ \\
\hline E. WCF Sumps & $\begin{array}{l}4000 \mathrm{gal} / \mathrm{yr} \text { for FY-96 thru FY- } 98 \text {. } \\
30: 1 \mathrm{PEW} \text { reduction then } 2: 1 \text { HLLWE } \\
\text { reduction. }\end{array}$ & Water from runoff and condensate. \\
\hline F. NWCF Decon Room & $\begin{array}{l}30,000 \mathrm{gal} / \mathrm{yr} \text { for non-campaign years. } \\
20,000 \mathrm{gal} / \mathrm{yr} \text { for campaign years. } \\
20: 1 \mathrm{PEW} \text { reduction then } 2: 1 \mathrm{HLLWE} \\
\text { reduction. }\end{array}$ & $\begin{array}{l}\text { Excludes filter leach but include debris } \\
\text { treatment on non-campaign years. Stream } \\
\text { consists mostly of nitric acid, water and } \\
\text { decon solutions. }\end{array}$ \\
\hline G. LET\&D & $\begin{array}{l}2000 \mathrm{gal} / \mathrm{yr} \text {. } \\
\text { 10:1 PEW reduction then 2:1 HLLWE } \\
\text { reduction. }\end{array}$ & Dilute nitric acid from upset conditions. \\
\hline H. CPP-603 - Wet Side & $\begin{array}{l}20,000 \mathrm{gal} / \mathrm{yr} \text { in FY- } 96 \text { through FY-98 } \\
\text { then } 1000 \text { gal/yr. } \\
\text { 30:1 PEW reduction then 2:1 HLLWE } \\
\text { reduction. }\end{array}$ & $\begin{array}{l}\text { Water from filter backwash, washdowns, } \\
\text { etc. }\end{array}$ \\
\hline I. CPP-603 - Dry Side & $\begin{array}{l}5000 \mathrm{gal} / \mathrm{yr} \text {. } \\
\text { 30:1 PEW reduction then 2:1 HLLWE } \\
\text { reduction. }\end{array}$ & $\begin{array}{l}\text { Water from washdowns, safety showers, } \\
\text { etc. }\end{array}$ \\
\hline J. Tank Farm Sumps & $\begin{array}{l}60,000 \mathrm{gal} / \mathrm{yr} \text {. } \\
30: 1 \mathrm{PEW} \text { reduction then } 2: 1 \text { HLLWE } \\
\text { reduction. }\end{array}$ & Water from storm runoff. \\
\hline K. Pilot Plants & $\begin{array}{l}1000 \mathrm{gal} / \mathrm{yr} \text {. } \\
10: 1 \mathrm{PEW} \text { reduction then 2:1 HLLWE } \\
\text { reduction. }\end{array}$ & From WL-104/105, expected to be acidic. \\
\hline
\end{tabular}


Table 1. (Continued)

\begin{tabular}{|c|c|c|}
\hline Waste Stream & $\begin{array}{l}\text { Volume Generation and } \\
\text { Evap. Reduction } \\
\end{array}$ & Comments and Concerns \\
\hline L. RCRA Wells & $\begin{array}{l}5000 \mathrm{gal} / \mathrm{yr} \text {. } \\
\text { 30:1 PEW reduction then 2:1 HLLWE } \\
\text { reduction. }\end{array}$ & Water from sampling RCRA wells. \\
\hline M. Misc. Balance of Plant & $\begin{array}{l}30,000 \mathrm{gal} / \mathrm{yr} \text {. } \\
\text { 30:1 PEW reduction then 2:1 HLLWE } \\
\text { reduction. }\end{array}$ & Includes jet dilution, PWL sumps, etc. \\
\hline N. PEW Descale & $\begin{array}{l}2000 \mathrm{gal} / \mathrm{yr} . \\
\text { 2:1 HLLWE reduction. }\end{array}$ & $\begin{array}{l}\text { No PEW reduction as this is descaling } \\
\text { chemical and rinses added directly to PEW } \\
\text { during maintenance. }\end{array}$ \\
\hline O. Other INEL & $\begin{array}{l}60,000 \mathrm{gal} / \mathrm{yr} \text {. } \\
\text { 30:1 PEW reduction then 2:1 HLLWE } \\
\text { reduction. }\end{array}$ & $\begin{array}{l}\text { TRA - } 50,000 \mathrm{gal} / \mathrm{yr} \text { water. } \\
\text { TAN - possible } 9600 \text { gal mixed waste } \\
\text { total. }\end{array}$ \\
\hline 14 - D\&D/Deactivation Activities & . & $\begin{array}{l}\text { There are several D\&D activities included } \\
\text { in the EIS, ROD, or STP which have not } \\
\text { been addressed in the above waste } \\
\text { streams. They are included here although } \\
\text { amounts generated are highly subject to } \\
\text { change. }\end{array}$ \\
\hline A. WCF (CPP-633) & 0 & $\begin{array}{l}\text { Current plans to grout this facility in place } \\
\text { in FY-98-99. Indications are than the state } \\
\text { will accept this approach on this facility. }\end{array}$ \\
\hline B. CPP-603 Fuel Storage & $\begin{array}{l}50,000 \text { gal total in FY-99 thru } \\
\text { FY-00. } \\
\text { 10:1 PEW reduction then } 2: 1 \text { HLLWE } \\
\text { reduction. }\end{array}$ & $\begin{array}{l}\text { This may go to zero if it is decided to grout } \\
\text { this facility in place with the same } \\
\text { approach as the WCF facility. }\end{array}$ \\
\hline $\begin{array}{l}\text { C. Fuel Processing Complex } \\
\text { (CPP-601) }\end{array}$ & 0 & $\begin{array}{l}\text { No plans currently for this facility although } \\
\text { it is included in the EIS and ROD as a } \\
\text { D\&D activity that is planned. }\end{array}$ \\
\hline D. Tank Farm Heel Removal & 0 & $\begin{array}{l}\text { This EIS and ROD indicates the liquid and } \\
\text { solid heels from the } 11 \text { tanks will be } \\
\text { removed (assumed starting around 2009). } \\
\text { However, current plans are to leave heels } \\
\text { in place and complete a RCRA closure. }\end{array}$ \\
\hline E. FDP (CPP-666) & 0 & No plans currently for this facility. \\
\hline 15 -Discretionary & $\begin{array}{l}\text { 12,000 gal/yr. } \\
\text { 2:1 HLLWE Reduction. }\end{array}$ & $\begin{array}{l}\text { This is to cover unplanned maintenance, } \\
\text { exceptionally wet weather, etc. }\end{array}$ \\
\hline
\end{tabular}

Also on the $D \& D$ projects, the current approach is to grout everything in place. This approach is expected to be approved for the WCF facility; however, it is unsure if it will be allowed for the CPP-603 basin and other areas.

This information was adjusted and modeling completed to determine the waste reduction achieved (Appendix B contains the detailed spreadsheets). The results of this update indicate that there has been a significant reduction in the waste generation goals from two years ago. If the updated baseline goals are met, 
a $35 \%$ waste reduction will be achieved. Figure 1 compare the original estimates and the current estimates. This waste reduction, coupled with an increase in the calcination rate, will enable the achievement of the goal to process the waste in the tank farm by 2012 (Figure 2). However, this does not mean that waste generation is no longer a problem. There must be a program in place to ensure these waste goals are met.

The team in the facilitated meeting felt an approach to ensure these goals are met as severe as that detailed in WINCO-1212 was not justified. This team recommend a "monitoring" program versus a "regulatory" program. Past recommendations suggested that each generator be approved for only a certain volume of waste per fiscal year and if they generated more they must get approval from a "regulatory" group. This will simply add to the already overwhelming regulation and needed approvals imposed on Operations and will be counterproductive. At this time, a monitoring and reporting function in conjunction with company level incentives will ensure these waste generation goals are met. This will provide the tool that responsible management personnel need to make decisions on the waste generating activities. Figure 3 is a logic diagram of this monitoring program.

The waste generation goals will be reviewed annually to ensure they reflect all of the current planning. The actual waste generation is monitored by an Integrated Product Team (IPT) consisting of waste generators from various plant areas and other essential personnel. The team contains representatives from NWCF, Tank Farm, CPP-603, FDP/FSA, CPP-601, PEW/LET\&D, and NWCF Decontamination Area as well as a representative from Engineering Support, Facility Deactivation and the Waste Management Authority. A representative from the Technology Development area is the coordinator of this team. The team meets quarterly and each representative reports the waste generation which occurred during the past quarter. These figures are discussed and compared to the baseline. Any significant deviations from the baseline are explained and justified. Once a year the baseline goals are reviewed and revised to reflect current and future plans for the various areas. This approach will aid in making the waste generators aware of the impact of the waste they are generating and help them to see the importance of reducing the waste generated.

Every six months the IPT coordinator provides a written report to LMITCO management detailing the status of the waste generation versus the goals. It will point out any significant deviations or problem areas. This report will make the waste generation goals more visible to each generator and to management. The responsible management personnel will also have the tools needed to impose stricter controls if the situation warrants them.

In addition, a company/DOE level incentive will be established on reaching the waste generation goals. This will help to keep waste generation an important issue when management is deciding the tradeoffs between items such as schedules, costs, and radiation exposures. There is currently no penalty for generating excessive waste. A company level incentive would result in most department managers setting up their own incentives and emphasize the importance of not generating excessive waste. 
Delta (New Value - Old Value), Gallons
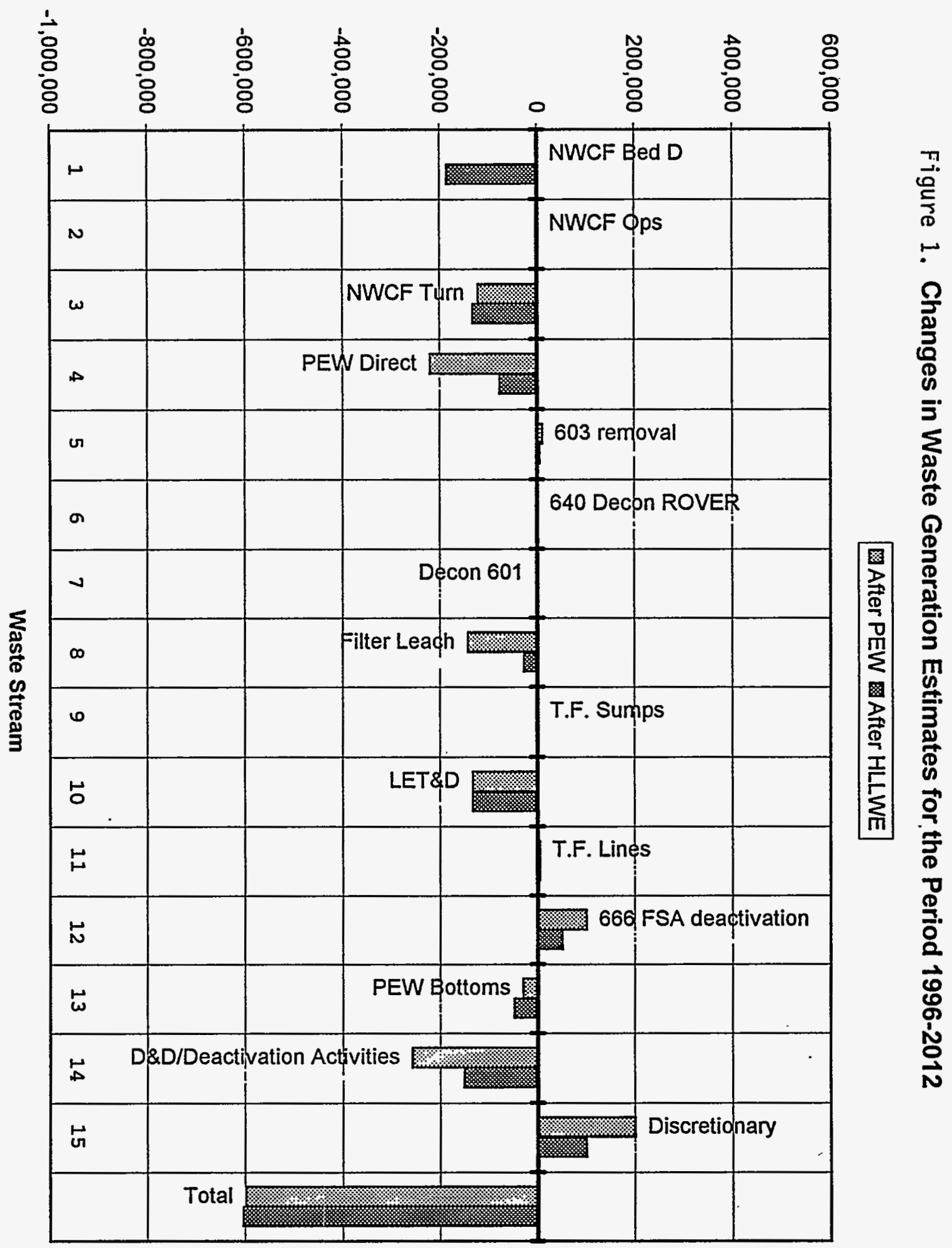

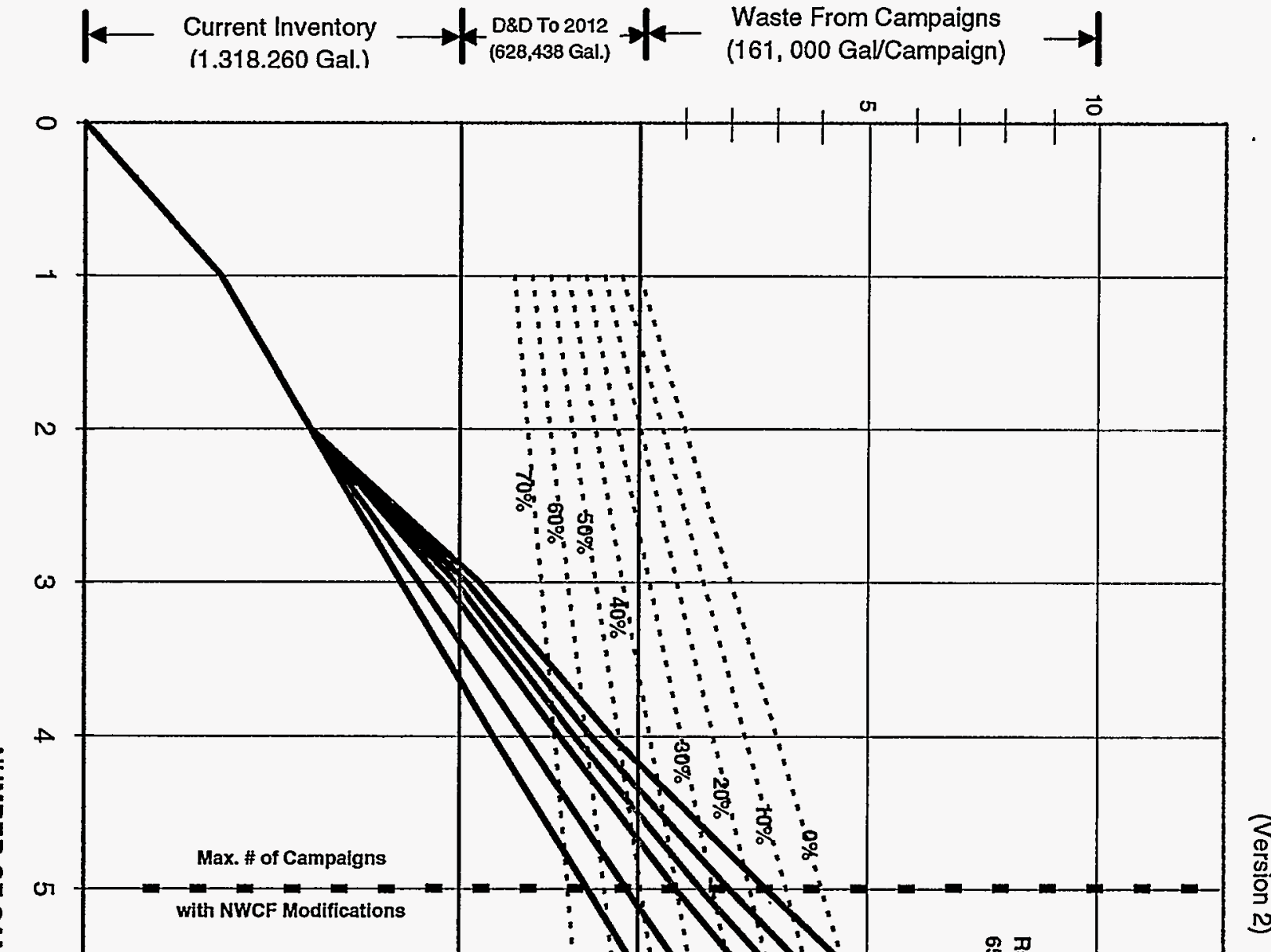

兽

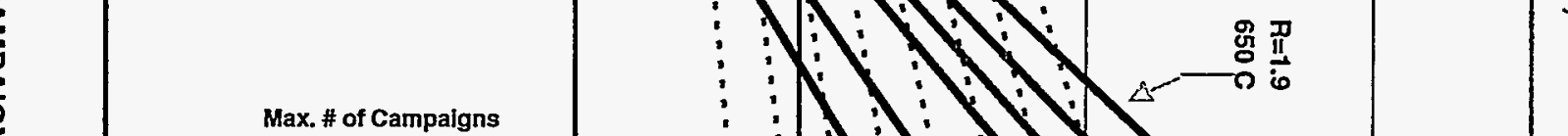

a

Max. \# of Campaigns

a

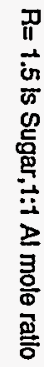
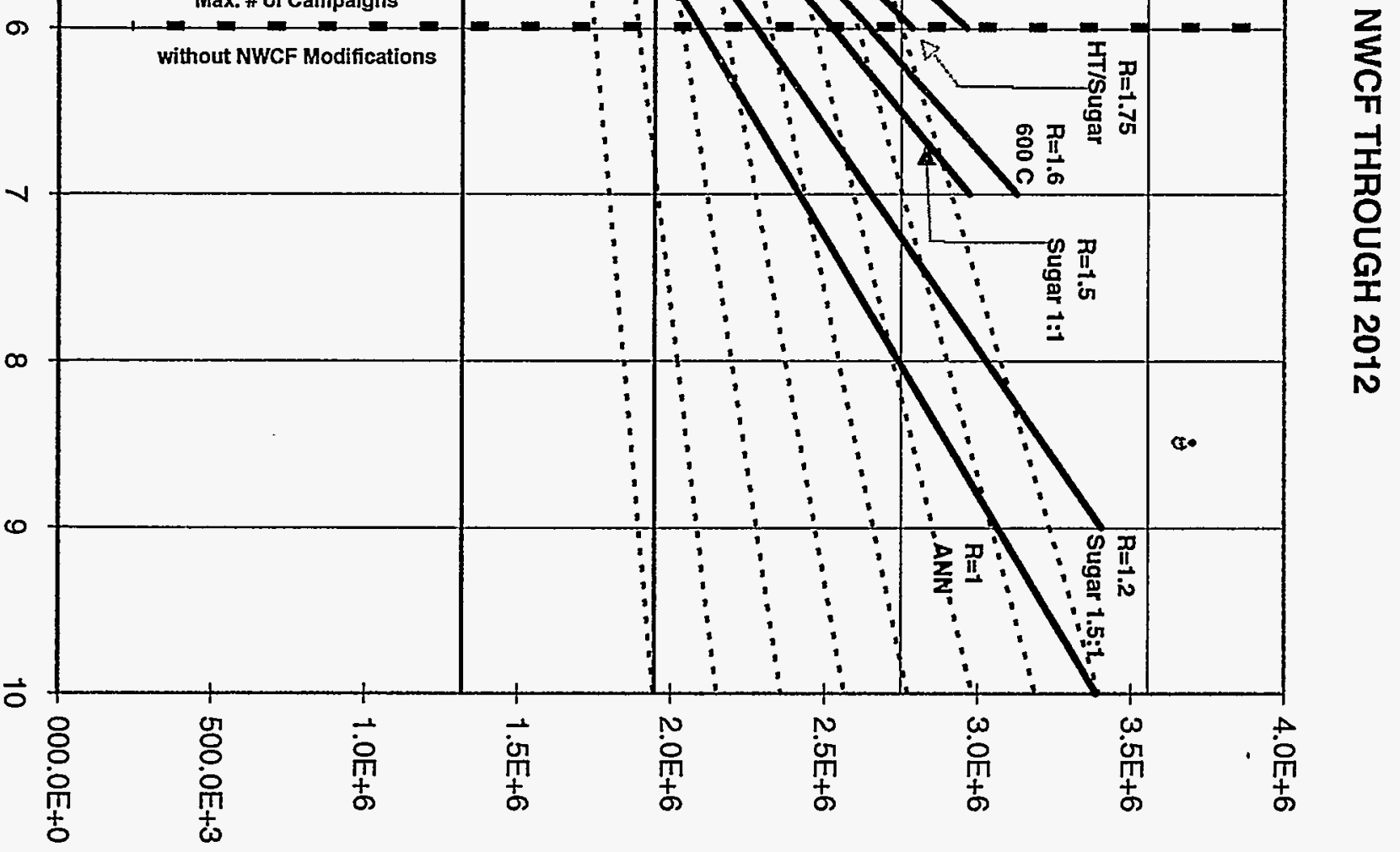

POST-EVAPORATIVE HLLW VOLUME (GAL., $\pm 5 \%$ ) 
Figure 3. Waste generation program logic diagram.

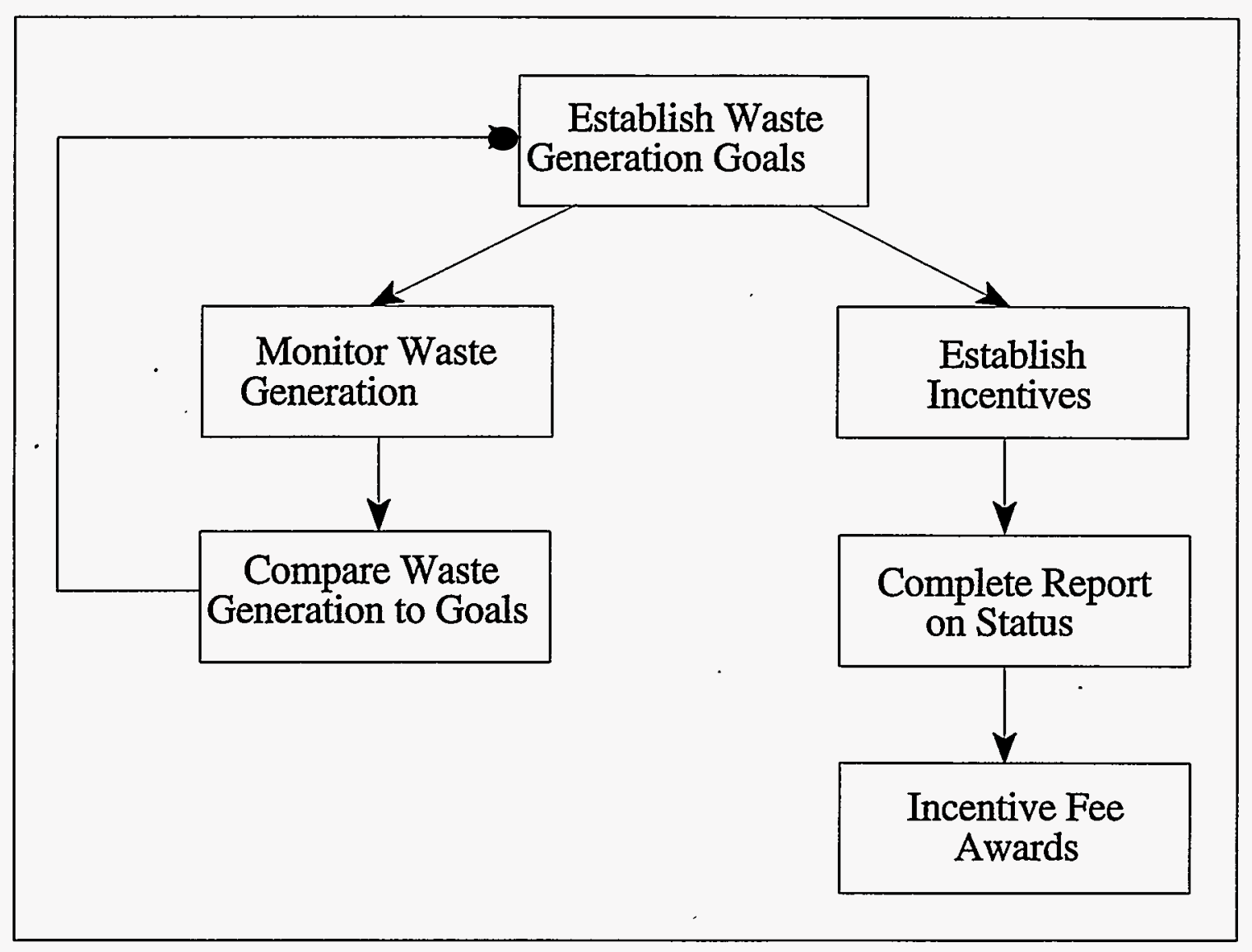

This portion of the HLW program will track waste being generated and compare these amounts to established goals to ensure meeting the 2012 date for removal of waste from the tank farm. The baseline waste generation goals will be revised yearly to capture the changing plans to schedules. 


\section{REFERENCES}

1. Palmer, W. B. et al, "ICPP Tank Farm Systems Analysis," WINCO-1192, Appendix B, January 1994.

2. Collins, J. W. et. al., "INEL Radioactive Liquid Waste Management Plan," WINCO-1212, May 1994.

3. Seward, Linda, letter to Julia L. Tripp, LCS-07-96, Waste Generation Meeting Summary Report, dated April 1, 1996 


\section{Appendix A Waste Stream Goals}




\section{Waste Stream \#1 - NWCF Bed Dissolutions}

Use 25,000 gallons per bed dissolution with 3 dissolutions per 18 month NWCF campaign. Due to the uncertainties with the agglomeration potential of the bed in the new flowsheets, this waste stream was not reduced to two dissolutions per run. These dissolutions are done with $6 \mathrm{M}$ nitric acid; however, since it is dissolved calcine, this solution will be sent directly to the Tank Farm, bypassing the PEW. A reduction of 2:1 in the HLLWE was anticipated. When calculating the amount of calcine generated from this waste, the fact that it is essentially dilute blended feed should be considered. If a 1000 gallon bed is assumed (a full bed is around 5000 gallons but usually most of this is transferred out as calcine solids), this is equivalent to about 7000 gallons of blended feed (using a 7:1 volume reduction in the calciner). Therefore, $56 \%$ [ $(7000$ )$/(25,000 / 2)]$ of this waste stream is actually blended feed and no additional ANN is required for this portion.

The Palmer report used the same assumptions for this waste stream but did not mention the fact it was partially blended feed and therefore the additional ANN requirement is reduced.

\section{Waste Stream \#2 - NWCF Operations}

Use 3000 gallons/month during NWCF campaigns. Assume no evaporator reduction since the nitric acid, fluoride, chloride, radioactivity and possibly mercury concentrations will not allow it to be sent to the PEWE or HLLWE. This waste stream includes the deep recycle of the scrub solution (1500 gallons each time), the absorber washes, and other sources like leak collection. A portion of this is equivalent to blended feed as it is essentially redissolved calcine. Assume $50 \%$ is equivalent to blended feed so no additional ANN is needed to calcine. This is historically a little high, however, it is possible the future flowsheets may cause more $\mathrm{Cl}$ and fines carryover which would increase this number.

The Palmer report used the same assumptions for this waste stream but did not consider that part of the stream was essentially blended feed and therefore the additional ANN requirement is reduced.

\section{Waste Stream \#3 - NWCF Turnaround}

Use 70,000 gallons of decon solution for a 12 month turnaround and 180,000 gallons for a 3-4 year turnaround. Approximately $40 \%$ of each of these stream would be routed direct to the tank farm with a subsequent HLLWE reduction of 2:1 because of the concentrations and radioactivity. The other $60 \%$ would be routed to the PEW for a 20:1 reduction with a subsequent HLLWE reduction of 2:1. These turnaround volumes assume no major vessel replacements. The 3-4 year turnaround would consist mainly of the off-gas and calciner cell decontaminations. This solution consists of nitric acid, dissolved calcine, water and various decon chemicals. This results in a total dilute volume of 570,000 gallons generated through 2012 or 122,550 gallons of evaporated volume.

The Palmer report assumed a total of 256,300 gallons of evaporated volume in the same time period.

Lower expected future activities is one of the reasons this number is less than previously expected. Highly dependent on schedule (if in a rush more chemical is generally generated). In the past campaign turnaround did very well in the calciner cell and off-gas cell but generated a lot in the filter banks because of inability to reach a plugged line any other way. More extensive decons may be used in the future to reduce radiation exposure and allow longer stay times in the cell. This is a tradeoff which will have to be evaluated. 


\section{Waste Stream \#4 - PEWE Direct to the Tank Farm}

Use 3000 gallons/year with a 2:1 HLLWE reduction. This is acid or other solutions with high chloride, organics, or other components not allowed in the PEW. This waste stream comes from the CPP-601 deep tanks (from analytical laboratories), CPP-641 west side tanks (from pilot plants), tank trucks and the fuel storage basins. This is waste normally sent to the $\mathrm{PEW}$, which for some reason (like high uranium, radioactivity, nitric acid, fluoride, chloride, or sulfate) cannot be processed in the PEW. This generates a total evaporated waste volume through 2012 of 25,500 gallons. The Palmer report assumed an evaporated volume during this same time period of 103,700 gallons.

In FY-92 and 93 this number was around $1000 \mathrm{gal} / \mathrm{yr}$ and in FY-94 and -95 it was around 3500 $\mathrm{gal} / \mathrm{yr}$ partly because of $2 \mathrm{nd}$ and $3 \mathrm{rd}$ cycle rinses. Since activity in general is decreasing, the amount going direct to the tank farm should be lower.

\section{Waste Stream \#5 - 603 Removal}

This waste stream is the water to be removed from the 603 basins after all of the fuel has been moved. These pools contain about 1.5 million gallons. Assume 50,000 gallons will be processed per month through the PEW at a reduction factor of $30: 1$ starting in FY-99 until all is processed. This will undergo a further reduction of 2:1 in the HLLWE. This assumes no flushes or sludge removal. Although this is deionized water it is quite dirty with desert dust and sludge and also contains about $50 \mathrm{ppm} \mathrm{Cl}$. To get a higher PEW reduction, LET\&D operation must be optimized (may require additional condensate tanks). A total of 25,000 gallons goes to the tank farm after evaporation. The normal flushes of the ion exchange units up until this time are covered under the PEW Bottoms waste stream.

The Palmer report estimated 20,000 gallons after evaporation. The current estimate is slightly higher because of budget constraints on obtaining spare parts for the evaporators which requires that they be operated more conservatively to ensure corrosion is controlled to a minimum.

Operations may be able to achieve a higher PEW reduction if the RCRA permit limit of $7000 \mathrm{gal}$ feed/day is eliminated and if adequate spare parts are provided for PEW maintenance.

\section{Waste Stream \#6 - ROVER Deactivation (CPP-640)}

Assume 10,000 gallons/yr for FY-98, -99 and -00 . This is water, nitric acid and decon solutions used to wash down the outside of equipment. Therefore, use a 20:1 PEW reduction factor and a 2:1 HLLWE reduction factor. This results in 750 gallons to the tank farm after evaporation. The Palmer report estimated 500 gallons to the tank farm after evaporation.

Uranium removal is currently taking place in the dry side. In FY-98, decon of the dry side including removal of all equipment will start. Plans may involve immobilizing contamination inside of pipes with a foam material then cutting out the pipes.

\section{Waste Stream \#7 - CPP-601 Decontamination}

Use 3000 gallons in FY-96 for the embedded line project. This will be water, nitric acid and decon solutions therefore use a 20:1 PEW reduction factor and a 2:1 HLLWE factor. No further work in CPP-601 is planned and all other waste streams from this building are included in the PEW bottoms number. This results in $\mathbf{7 5}$ gallons to the tank farm after evaporation compared to 1152 gallons from the Palmer report. 


\section{Waste Stream \#8 - Filter Leach}

The maximum number of filters that can be processed in a year are 115 according to the Site Treatment Plan. Use this number, although less could be processed (more like 80/yr), since the final resulting volume will be the same. Each filter requires three 60 gallon 3M nitric acid flushes followed by two 60 gallon water flushes. All of this solution from the test filters (which were supposed to be some of the worst filters) was sent to the PEW (mixed with other wastes coming out of the decon shop). Use a 10:1 reduction factor in the PEW and another 2:1 in the HLLWE. There are currently 256 filters in storage at the NWCF, 147 in FDP (which are processed 6 filters per batch as these are small filters) and 34 at RWMC. There is a chance that filters from other facilities will be processed but that is not included in this amount. Assume additional filters are being generated at a rate of 2 filters every 10 days of NWCF operation (with no filters being generated during shutdown periods), 1 filter per year from the VOG, 5 filters per year from the Process Atmospheric Protection System (PAPS), 8 filters per year from LET\&D and 104 filters in the Ventilation Atmospheric Protection System in FY-98. The WCF filters (10 large filters) will be grouted in place.

This results in an evaporated tank farm volume of 17,970 gallons compared to the Palmer estimate of 49,415 gallons (difference primarily because of possible evaporation).

\section{Waste Stream \#9 - Tank Farm Sumps to Tank Farm}

Use 100 gallons/yr with no further reduction. Most of the sump water is sent to the PEW, however, this is the amount that cannot be sent to the PEW because of the piping arrangement or high activity in the water from valve leaks. The Palmer report also used $100 \mathrm{gal} / \mathrm{yr}$.

\section{Waste Stream \#10 - LET\&D to Tank Farm}

This stream is the concentrated bottoms from the LET\&D process. Currently the acid recycle tank is not in service because of some procedural changes and other items which must be addressed to obtain DOE approval. It is anticipated this will be in service by the first of FY-97. After this date, all concentrated acid from these bottoms will be used in processing or decontamination operations. For FY-96, this stream is 3500 gallons of $13 \mathrm{M}$ nitric acid with no further evaporator reduction due to the high molarity. This number is based on historical numbers (FY-93 - 5600 gal, FY-94 - 6750 gal, FY:95 - 3400 gal). The acid recycle tank is 20,000 gallons, therefore, even for a four year shut down there should be sufficient storage space for all of this nitric acid.

The Palmer report estimated a higher generation rate (15,000 gallons/yr vs $3500 \mathrm{gal} / \mathrm{yr})$ than current operations indicates. Therefore, the total volume of this waste stream to the tank farm was around 137,500 gallons in past reports. 


\section{Waste Stream \#11 - Tank Farm Line Flushes}

Assume $1000 \mathrm{gal} / \mathrm{yr}$ to the tank farm with no further reduction. This covers upgrades to six valve boxes and other maintenance work. Some years this is higher and others will be at zero, therefore this should be a good average.

The Palmer report uses 500 gallons/yr.

\section{Waste Stream \#12 - FSA Deactivation}

Current plans indicate that the fuel will be moved out of the Fuel Storage Area (FSA) in FAST by FY-2008. The Navy is building their own dry storage. This will then require the processing of the water in these 6 pools. The pools hold approximately 3.2 million gallons of water. Assume this is processed 50,000 gallons/month through the PEW until gone at a 30:1 PEW reduction then a 2:1 HLLWE reduction. A high reduction may be achieved, but because of current practice of mixing with other wastes and the fact there is not money for evaporator repairs necessitating a very conservative operation this reduction was estimated fairly low in this case.

This stream was not addressed in the Palmer report.

\section{Waste Stream \#13 - PEW Boltoms}

The Palmer report addressed this as one waste stream generating 25,000 gallons/yr. Later in modeling this was changed to 10,000 gallons/yr. Historically this amount has ranged from FY-92 - 11250 gal, FY-93 - 12750 gal, FY-94 - 21400 gal, FY-95 - 10750 gal.

Because the idea is to track the generation of these wastes this report broke the streams down into individual waste streams. These streams are detailed below:

\section{A - NWCF Operations}

This is estimated to be $2500 \mathrm{gal} / \mathrm{mo}$ during NWCF operations from floor drains, etc. and is covered under the NWCF turnaround waste stream (\# 3) during non operating periods. This waste can be reduced 20:1 in the PEW then 2:1 in the HLLWE. During operations this is frequently recycled to the calciner feed batches. This consists of water and decon solutions. (NCC-122).

\section{B - FAST FSA}

Assume $25,000 \mathrm{gal} / \mathrm{yr}$ until deactivation in 2008. This is water from filter backwashes and cask washes. This can be reduced in the PEW at 30:1 then 2:1 in the HLLWE. This is based on one backwash per month at 1000 gallons each plus 12,000 gallons/yr for cask and rack washdowns and sumps.

\section{C - FAST FDP}

Assume $3000 \mathrm{gal} / \mathrm{yr}$ of mostly water from safety shower checks and periodic mop downs. This can be reduced in the PEW at 30:1 then 2:1 in the HLLWE. 


\section{D - Cell Floor Drains}

Assume $36,000 \mathrm{gal} / \mathrm{yr}$ from the CPP-601 deep tanks. This is mostly analytical waste and therefore could be high chloride. All RCRA flushes of CPP-601 are compete. Some additional waste is expected to be generated from the sumps (1000 gal/yr). Past history, from FY-92 to FY-93, shows higher numbers because of 2 nd and 3rd cycle operations and subsequent flushes. In the Collins report, this waste stream volume was 75,000 gal/yr. Assume a 20:1 PEW reduction then a 2:1 HLLWE reduction.

\section{E - WCF Sumps}

Assume $4000 \mathrm{gal} / \mathrm{yr}$ for FY-96 through FY-98. This is water from runoff and steam condensate. Historical values put this around $6000-9000 \mathrm{gal} / \mathrm{yr}$ but some work has been completed by berming areas to reduce the amount collected from runoffs. After FY-98, it is anticipated this structure will undergo RCRA closure. The current plan is to grout the building in place.

\section{F - NWCF Decon Room}

Assume 30,000 gal/yr in non-campaign years for debris treatment and other decontamination activities (excludes filter leach). Assume 20,000 gal/yr for campaign years (excludes filter leach). This is nitric acid, water and decontamination solutions and can be reduced in the PEW at 20:1 then in the HLLWE at 2:1.

\section{G - LET\&D}

Assume $2000 \mathrm{gal} / \mathrm{yr}$ at a 10:1 PEW reduction and a 2:1 HLLWE reduction. This stream covers the dilute nitric acid which would be routed to the PEW under upset conditions in the LET\&D.

\section{H - CPP-603 - Wet Side}

Assume 20,000 gal/yr in FY-96 through FY-98 will be generated from filter backwashes and other operations. After this the water will be removed from the pools as the facility undergoes a closure. Assume $1000 \mathrm{gal} / \mathrm{yr}$ after this because of a few systems expected to remain for liquid collection. This has a 30:1 PEW reduction and then a 2:1 HLLWE reduction.

\section{I - CPP-603 Dry Side}

Assume $5000 \mathrm{gal} / \mathrm{yr}$ for water from washdown, safety showers, etc. This should have a 30:1 PEW reduction then a 2:1 HLLWE reduction.

\section{J - Tank Farm Sumps}

Assume $60,000 \mathrm{gal} / \mathrm{yr}$ of water from storm runoff. Some years this is $80,000 \mathrm{gal}$ and others much lower; completely weather dependent. Assume a 30:1 PEW reduction then a 2:1 HLLWE reduction.

\section{K - Pilot Plants}

Assume $1000 \mathrm{gal} / \mathrm{yr}$ from WL 104/105. This could be a variety of probably acidic solutions. Assume a 10:1 PEW reduction then a 2:1 HLLWE reduction. 


\section{L - RCRA Wells}

Assume $5000 \mathrm{gal} / \mathrm{yr}$ from water sampling activities on RCRA wells. This will have a 30:1 reduction in the PEW then a 2:1 reduction in the HLLWE.

\section{M - Misc. Balance of Plant}

Assume 30,000 gal/yr covers jet dilution, PWL sumps and other plant sources. This will have a 30:1 PEW reduction then a 2:1 HLLWE reduction.

\section{N - PEW Descale}

Assume $2000 \mathrm{gal} / \mathrm{yr}$ with a 2:1 HLLWE reduction. This is chemical added to the PEW to remove scale (and therefore ends up in the bottoms) The chemicals used are generally high sodium chemicals such as TURCO 4502.

\section{O - Other INEL}

The ICPP may still receive liquid waste from other INEL sites. These include TRA ( $50,000 \mathrm{gal} / \mathrm{yr})$, and 9600 gallons from TAN. Include $60,000 \mathrm{gal} / \mathrm{yr}$ in this waste stream to cover the possibilities. This should have a 30:1 PEW reduction then a 2:1 HLLWE reduction.

\section{4 - D\&D/Deactivation Activities}

NOTE: There are several D\&D activities included in the EIS, ROD or STP which have not been addressed in the above waste streams. These are included here although amounts generated are highly subject to change.

\section{A - WCF (CPP-633)}

Current plans are to grout this facility in place in FY-98 and -99. Current indications are that the state will accept this approach on this facility.

\section{B - CPP-603 Fuel Storage}

Assume 50,000 gal total in FY-99 thru FY-00 to remove sludge and decon activities. This will have a 10:1 PEW reduction then a 2:1 HLLWE reduction. This may go to zero if it is decided to grout this facility in place with the same approach as the WCF facility.

\section{C - Fuel Processing Complex (CPP-601)}

There are no current plans for this facility although it is included in the EIS and the ROD as a D\&D activity that is planned.

\section{D - Tank Farm Heel Removal}

The EIS and ROD indicates the liquid and solid heels from the 11 tanks will be removed (assumed starting around 2009). However, current plans are to leave heels in place and complete a RCRA closure. 


\section{E - FDP (CPP-666)}

No current plans to deactivate this facility.

\section{5 - Discretionary}

Include a discretionary volume of $12,000 \mathrm{gal} / \mathrm{yr}$ (with a 2:1 HLLWE reduction) to cover unplanned maintenance, exceptionally wet weather, etc. 


\section{Appendix B \\ Modeling Results}


Goal Scenario. Incorporating J.L. Tripp Datu for 3/27/96,

type; $2=$ non-sodium-acid-decon(H+) waste type.

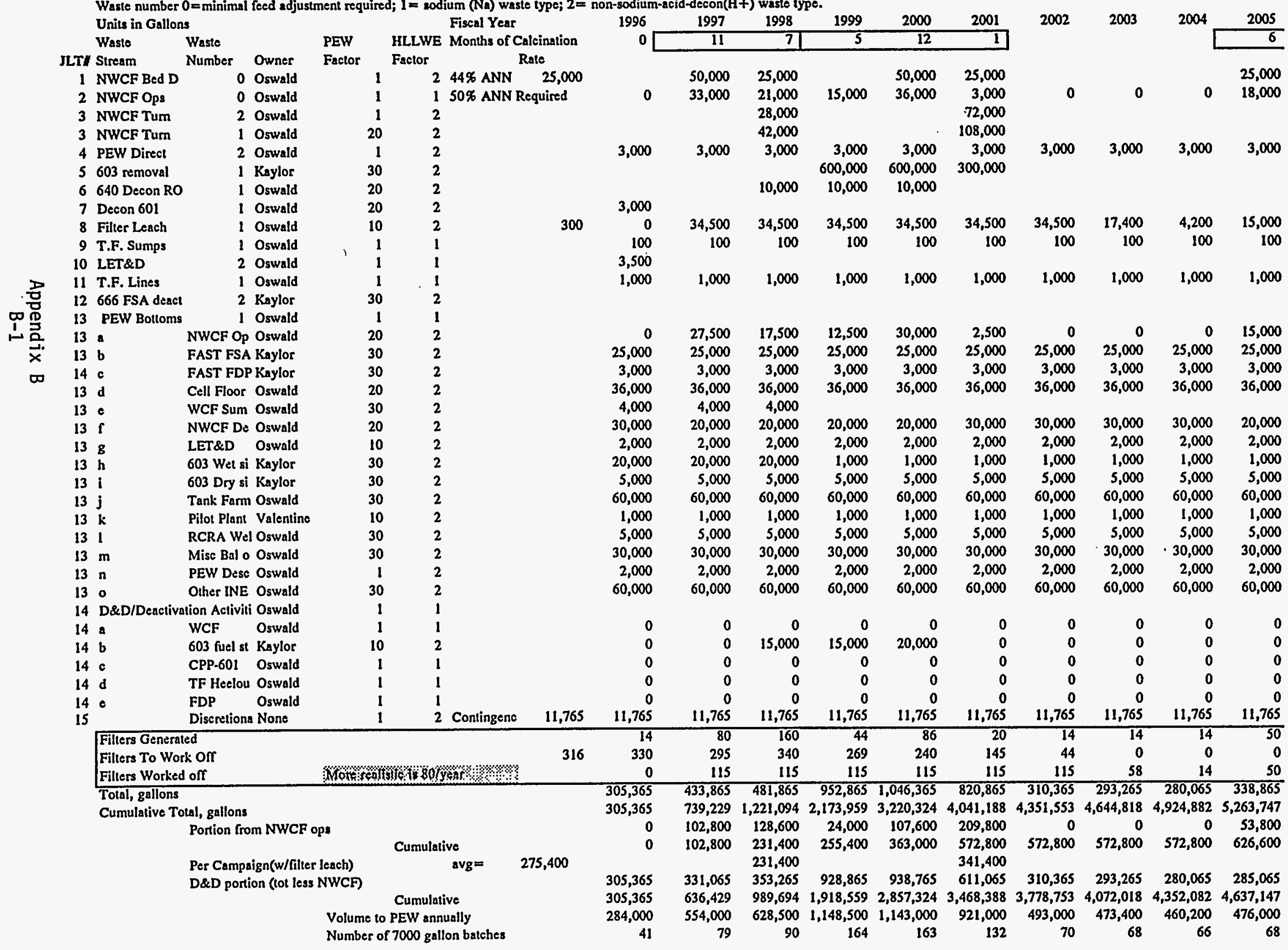




\begin{tabular}{|c|c|c|c|c|c|c|c|c|c|c|c|c|c|c|c|c|}
\hline $88 \nabla^{\prime} 998^{\prime} S$ & $\begin{array}{l}009^{\prime} Z \forall S^{\prime} 6 \\
000^{\prime} \angle L \varepsilon^{t} I \\
000^{\prime} \angle L E^{\prime} I \\
009^{\prime} 616^{\prime} 0 \mathrm{I}\end{array}$ & $\begin{array}{l}0 z I^{\prime} \tau \\
00 \tau^{\prime} \tau \$ 8^{\prime} \forall I \\
6 S 8^{\prime} Z 9 L^{\prime} 01 \\
000^{\circ} \angle L \varepsilon^{\prime} I \\
000^{\prime} \angle L \varepsilon^{\prime} I \\
6 S 8^{\prime} 6 \varepsilon I^{\prime} Z I\end{array}$ & $\mid$\begin{tabular}{||l}
$6 S$ \\
$60 z^{\prime} 01 t$ \\
$658^{\prime} z 9 L^{\prime} 01$ \\
$590^{\prime} S S Z$ \\
\\
$000^{\circ} \angle L E^{\prime} I$ \\
0 \\
$6 S 8^{\circ} 6 \varepsilon I^{\prime} Z I$ \\
$S 90^{\circ} S S Z$
\end{tabular} & $\begin{array}{l}6 S \\
00 Z^{\prime} 016 \\
66 L^{\circ} \angle O S^{\prime} 01 \\
S 900^{\circ} S S Z \\
000^{\prime} \angle L E^{\prime} I \\
0 \\
66 L^{\prime} \forall 88^{\prime} I I \\
S 90^{\circ} S S Z\end{array}$ & $\begin{array}{l}6 S \\
00 Z^{\prime} 01 t \\
6 Z L^{\prime} Z S Z^{\prime} 0 I \\
S 90^{\circ} S S Z \\
\\
000^{\prime} \angle L E^{\prime} I \\
0 \\
6 Z L^{\prime} 6 Z 9^{\prime} I 1 \\
S 90^{\circ} S S Z\end{array}$ & 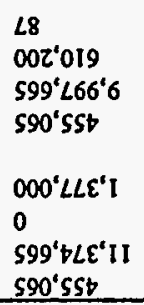 & $\begin{array}{l}\angle \$ 1 \\
00 Z^{\prime} 0 E 0^{\prime} \mathrm{I} \\
009^{\prime} Z \not S^{\prime} 6 \\
S 90^{\prime} S S 8 \\
\\
000^{\prime} \angle L \varepsilon^{\prime} \mathrm{I} \\
0 \\
009^{\prime} 616^{\prime} 01 \\
S 90^{\prime} S S 8 \\
\end{array}$ & 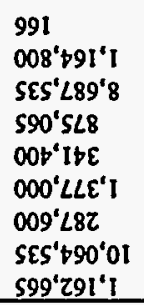 & 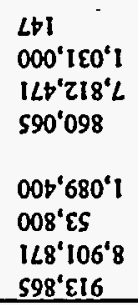 & 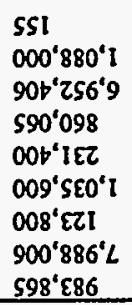 & 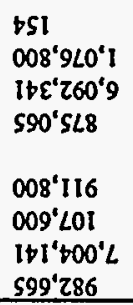 & $\begin{array}{l}\text { SL } \\
00 Z^{\prime} Z 2 S \\
9 L Z^{\prime} \angle I Z^{\prime} S \\
\text { S90'08Z } \\
00 Z^{\prime}+08 \\
000^{\prime} 0 L \\
9 L b^{\prime} 120^{\prime} 9 \\
\text { S90'OSE }\end{array}$ & 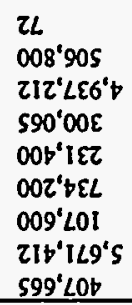 & 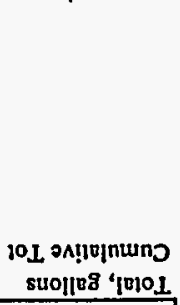 & & \\
\hline $88 \mathrm{t}^{\prime} 998^{\prime} \mathrm{C}$ & $002^{\prime} 616^{\prime} 01$ & $658^{\prime} 65 I^{\prime} \tau L$ & $\begin{array}{l}b 1 \\
0 \\
01\end{array}$ & $\begin{array}{l}1 \\
0 \\
t I\end{array}$ & $\begin{array}{l}b 1 \\
0 \\
01 \\
\end{array}$ & $\begin{array}{l}01 \\
0 \\
+1 \\
\end{array}$ & $\begin{array}{l}t \\
0 \\
01 \\
\end{array}$ & $\begin{array}{l}98 \\
0 \\
98 \\
\end{array}$ & $\begin{array}{l}0 S \\
0 \\
0 S\end{array}$ & $\begin{array}{l}05 \\
0 \\
0 S\end{array}$ & $\begin{array}{l}98 \\
0 \\
98 \\
\end{array}$ & $\begin{array}{l}01 \\
0 \\
+1 \\
1\end{array}$ & $\begin{array}{l}98 \\
0 \\
98 \\
\end{array}$ & 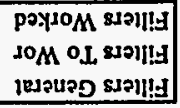 & & \\
\hline $\begin{array}{l}88 S^{\prime} 0 L Z \\
0\end{array}$ & $\begin{array}{l}000^{\prime} 00 t \\
0\end{array}$ & $\begin{array}{l}650^{\circ} \angle b 2 \\
0\end{array}$ & $\$ \int_{0}^{S 9 L ' I I}$ & $\begin{array}{l}S 9 L^{\prime} I 1 \\
0\end{array}$ & $\begin{array}{l}\$ 9 L^{\prime} 11 \\
0\end{array}$ & $\begin{array}{l}S 9 L^{\prime} I I \\
0\end{array}$ & $\begin{array}{l}\text { S9L'II } \\
0\end{array}$ & $\begin{array}{l}S 9 L^{\circ} I I \\
0\end{array}$ & $\begin{array}{l}S 9 L^{\prime} I I \\
0\end{array}$ & $\begin{array}{l}S 9 L^{\prime} I I \\
0\end{array}$ & $\begin{array}{l}S 9 L^{\prime} I I \\
0\end{array}$ & $\begin{array}{l}S 9 L^{\circ} 11 \\
0\end{array}$ & $\begin{array}{l}\$ 9 L^{\prime} 11 \\
0\end{array}$ & o & $S I$ & \\
\hline 0 & 0 & 0 & 0 & 0 & 0 & 0 & 0 & 0 & 0 & 0 & 0 & 0 & 0 & $\mathbf{p}$ & $t$ & \\
\hline 0 & $\mathbf{0}$ & 0 & $\| 0$ & 0 & 0 & 0 & 0 & 0 & 0 & 0 & 0 & 0 & 0 & o & $b 1$ & \\
\hline 0 & $000^{\prime} 05$ & $000^{\circ} 05$ & |jo & 0 & $\mathbf{0}$ & 0 & 0 & 0 & 0 & 0 & 0 & 0 & 0 & $q$ & $t i$ & \\
\hline $\mathbf{0}$ & 0 & 0 & $\| 0$ & 0 & 0 & 0 & 0 & 0 & 0 & 0 & 0 & 0 & 0 & B & $t i$ & \\
\hline $\mathbf{0}$ & $\mathbf{0}$ & $\mathbf{0}$ & & & & & & & & & & & & 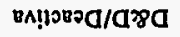 & $t i$ & \\
\hline $000^{\prime} 08 \varepsilon^{\prime} \mathrm{I}$ & I & $000^{\prime} 09 z^{\prime} 1$ & $\| 000^{\prime} 09$ & $000^{\circ} 09$ & $000^{\prime} 09$ & 000409 & $000^{\prime} 09$ & $000^{\circ} 09$ & $000^{\circ} 09$ & $000^{\prime} 09$ & $000^{\prime} 09$ & 000409 & $000^{t} 09$ & 0 & $\varepsilon I$ & \\
\hline $000^{\prime} 96$ & $000^{\prime}+\varepsilon$ & $000^{\prime} z t$ & $000^{\prime} z$ & $000^{\prime} \tau$ & $000^{\circ} \tau$ & $000^{\circ} \tau$ & $000^{\prime} \tau$ & $000^{\circ} \mathrm{z}$ & $000^{\circ} \tau$ & $000^{\prime} \tau$ & $000^{\prime} \tau$ & $000^{\prime} \tau$ & $000^{2} \tau$ & $\mathbf{u}$ & $\varepsilon I$ & \\
\hline $000^{4} 069$ & 000 '015 & $000^{\prime} 0 \varepsilon 9$ & |000'0ع & $000^{\circ} 0 \varepsilon$ & $000^{\prime} 0 \varepsilon$ & $000^{\prime} 0 \varepsilon$ & $000^{\prime} 0 E$ & $000^{\prime} 0 \varepsilon$ & $000^{\prime} 0 \varepsilon$ & $000^{\prime} O E$ & $000^{\prime} 0 \varepsilon$ & $000^{\prime} 0 E$ & $000^{\prime} 0 \varepsilon$ & u & EI & \\
\hline $000^{\prime} \mathrm{sII}$ & $000^{\prime} 58$ & 000 's0I & $\| 000^{\prime} s$ & $000^{\circ} \mathrm{s}$ & $000^{\circ} \mathrm{s}$ & $000^{\circ} \mathrm{s}$ & $000^{\circ} \mathrm{s}$ & 000 's & $000^{\circ} \mathrm{s}$ & $000^{\circ} s$ & $000^{\circ} s$ & $000^{\prime} s$ & $000^{\circ} \mathrm{s}$ & I & ยI & \\
\hline $000^{\prime} \varepsilon Z$ & $000^{\circ} \angle I$ & $000^{\prime} 12$ & $\| 000^{\prime} 1$ & $000^{\prime} 1$ & $000^{\prime} 1$ & $000^{\prime} \mathrm{I}$ & $000^{\prime} I$ & II I & $000^{\prime} \mathrm{I}$ & $000^{\prime} 1$ & II I & $000^{\prime} \mathrm{I}$ & $000^{t} 1$ & $y$ & $\varepsilon I$ & \\
\hline $000^{\circ} 08 E^{\prime} I$ & $000^{\circ} 020^{\prime} 1$ & $000^{\prime} 09 Z^{\prime} t$ & $0000^{\prime} 09$ & $000 \div 09$ & $000^{\prime} 09$ & $000^{\prime} 09$ & 000409 & 000409 & $000^{\prime} 09$ & $000^{\prime} 09$ & $000^{\prime} 09$ & $000^{\prime} 09$ & $000 ' 09$ & ! & $\varepsilon I$ & \\
\hline $000^{\circ}$ sII & $000^{\prime} 58$ & $000^{s} \mathrm{~s} 01$ & $\| 000^{\prime} s$ & $000^{\circ} \mathrm{s}$ & $000^{\prime} \mathrm{s}$ & 000 's & $000^{\prime} s$ & $000^{\prime} s$ & $000^{\prime} \mathrm{s}$ & 000 's & 000 's & $000^{\circ} \mathrm{s}$ & 000 's & ! & $\varepsilon I$ & \\
\hline $000^{\prime} \varepsilon \tau$ & $000^{\prime}+L$ & $000^{\prime} 8 L$ & ז'ו & $000^{\prime} t$ & $000^{\circ} 1$ & $000^{\prime} 1$ & $000^{\prime} I$ & $000^{\prime} I$ & $000^{4} t$ & $000^{*} 1$ & $000^{\prime} 1$ & $000^{\prime} 1$ & $000^{\prime} 1$ & y & $\varepsilon$ & \\
\hline $000^{\prime} 9 t$ & $000^{\circ} \forall \varepsilon$ & $000^{\prime} z t$ & $1000^{\circ} \tau$ & $000^{\circ} \tau$ & $000^{\circ} \tau$ & $000^{\prime} \tau$ & $000^{\circ} \tau$ & $000^{\circ} \tau$ & $000^{\prime} \tau$ & $000^{\prime} z$ & $000^{\circ} \mathrm{r}$ & $000^{\circ} \tau$ & $000^{\prime} \mathrm{r}$ & 8 & El & \\
\hline $\begin{array}{l}000^{\circ} 069 \\
0\end{array}$ & $\begin{array}{l}000^{\circ} 016 \\
000^{\prime} \mathrm{Zl}\end{array}$ & $\begin{array}{l}000^{\prime} 0 \varepsilon S \\
000^{\prime} \mathrm{zl}\end{array}$ & $\| 000^{\circ} 0 \varepsilon$ & $000^{\circ} 0 \varepsilon$ & $000^{\prime} 0 \varepsilon$ & $000^{\prime} 0 \varepsilon$ & $000^{`} 0 \varepsilon$ & $000^{\prime} 0 z$ & $000^{6} 0 \tau$ & $000^{\prime} 02$ & $000^{\prime} 02$ & $000^{\circ} 0 E$ & $000^{\prime} 0 \tau$ & $\begin{array}{l}1 \\
2\end{array}$ & $\begin{array}{l}\varepsilon l \\
\varepsilon l\end{array}$ & $\infty$ \\
\hline $000^{\prime} 828$ & $000^{\prime} z 19$ & $000^{\circ} 95 L$ & $1000^{\prime} 9 \varepsilon$ & $000^{\prime} 9 \varepsilon$ & $000^{\prime} 9 \varepsilon$ & $000^{4} 9 \varepsilon$ & $000^{\prime} 9 \varepsilon$ & $000^{\prime} 9 \varepsilon$ & $000^{\prime} 9 \varepsilon$ & $000^{\prime} 9 \varepsilon$ & $000^{\prime} 9 \varepsilon$ & $000^{\prime} 9 \varepsilon$ & $000^{\prime} 9 \varepsilon$ & $\mathbf{p}$ & $\varepsilon I$ & \\
\hline $000^{\prime} 69$ & $000^{\prime}$ is & $000^{\prime} \varepsilon 9$ & $000^{\prime} \varepsilon$ & $000^{\prime} \varepsilon$ & $000^{\prime} \varepsilon$ & $000^{\prime} \varepsilon$ & $000^{\circ} \varepsilon$ & $000^{\prime} \varepsilon$ & $000^{\circ} \varepsilon$ & $000^{\prime} \varepsilon$ & $000^{\prime} \varepsilon$ & $000^{2} \varepsilon$ & $000^{\circ} \varepsilon$ & o & $t \boldsymbol{l}$ & $\bar{Z}$ \\
\hline 0 & $000^{\circ} 00 \varepsilon$ & $000^{\circ} 00 \varepsilon$ & & & & & & & & & & $000^{\prime} s \tau$ & $000^{\circ} s 2$ & $\mathbf{q}$ & $\varepsilon$ & $\stackrel{\infty}{\infty}$ \\
\hline 0 & $000^{\prime} 522$ & $000^{\prime} s 2 \tau$ & $\mid 0$ & 0 & $\mathbf{0}$ & $\mathbf{0}$ & 0 & $000^{\prime} 0 \varepsilon$ & $000^{\prime} S I$ & $000^{\circ} S I$ & $000^{\circ} 0 \varepsilon$ & 0 & $000^{\circ} \mathrm{OE}$ & - & EI & $\bar{q}$ \\
\hline 0 & 0 & & & & & & & & & & & & & sw0110g Mad & $\mathcal{E} \mathbf{I}$ & \\
\hline 0 & $000^{\circ} 000^{\circ} \varepsilon$ & $000^{\prime} 00 \tau^{\prime} \varepsilon$ & & & & $000^{\prime} 002$ & $000^{2} 009$ & $000^{\prime} 009$ & 000 '009 & $000^{\prime} 009$ & $000^{\prime} 009$ & & & 10rep VSH 999 & $Z I$ & \\
\hline $\begin{array}{l}000^{\prime} \varepsilon \tau \\
0\end{array}$ & $\begin{array}{l}000^{\prime} \angle I \\
00 s^{\prime} \varepsilon\end{array}$ & $\begin{array}{l}000^{\prime} 1 \tau \\
00 s^{\prime} \varepsilon\end{array}$ & $1000^{\prime} 1$ & $0000^{\circ} t$ & $000^{\prime} 1$ & $000^{\circ} 1$ & $000^{4} I$ I. & $000^{\prime} \mathrm{I}$. & $000^{4} I$ & $000^{\prime} I$ & $000^{\prime} t$ & 000 ז I & $000 \times 1$ & 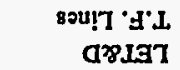 & $\begin{array}{l}11 \\
0 I\end{array}$ & \\
\hline $00 \varepsilon^{\prime} z$ & $00 L^{\prime} I$ & $00 I^{\prime} z$ & bot & 001 & 001 & 00I & 001 & $\infty 01$ & 00I & 001 & ool & $00 \mathrm{I}$ & 001 & sduuns :A L & 6 & \\
\hline $009^{\prime} 96$ & $00 b^{\prime} 6 S \varepsilon$ & OOZ' $9 L \varepsilon$ & ooz't & $00 \tau^{c}$ & $00 z^{2} \phi$ & $00 z^{\prime} b$ & $00 \tau^{\prime} b$ & $008^{\prime} s 2$ & $000^{\prime} \mathrm{SI}$ & $000^{\circ} S I$ & $008^{\prime} s t$ & $00 z^{\prime} b$ & 008 'st & पจำ รอ1)!ม & 8 & \\
\hline 0 & $000^{\prime} \varepsilon$ & $000^{\prime} \varepsilon$ & & & & & & & & & & & & 109 uosed & $c$ & \\
\hline 0 & $000^{\circ} 0 \varepsilon$ & $000^{\circ} 0 \varepsilon$ & & & & & & & & & & & & O\& uoved 0b9 & 9 & \\
\hline & $000^{\prime} 00 s^{\prime} t$ & $000^{\prime} 005^{4} I$ & & & & & & & & & & & & ן09 & $s$ & \\
\hline $\begin{array}{l}000^{\prime} 69 \\
0\end{array}$ & $\begin{array}{l}000^{\prime} I S \\
000^{\prime} z b \varepsilon\end{array}$ & $000^{\circ} \varepsilon 9$ & $\| 000^{*} \varepsilon^{\circ}$ & $000^{\prime} \varepsilon$ & $000^{\circ} \varepsilon$ & $000^{\circ} \varepsilon$ & $000^{\circ} \varepsilon$ & $000^{\prime} \varepsilon$ & $000^{\prime} \varepsilon$ & $000^{\prime} \varepsilon$ & $000^{\circ} \varepsilon$ & $000^{4} \varepsilon$ & $000^{\circ} \varepsilon$ & 1021! $\mathrm{MBd}$ & 6 & \\
\hline 0 & $000^{\prime} 8 z \tau$ & $000^{\circ} 822$ & & & & & & $\begin{array}{l}000^{\circ} 801 \\
000^{\circ} \mathrm{ZL}\end{array}$ & & $\begin{array}{l}00026 \\
000^{\circ} 82\end{array}$ & & $\begin{array}{l}000^{\prime} z 6 \\
000^{\prime} 82\end{array}$ & & $\begin{array}{l}\text { wn,L } J D M N \\
\text { wnLL } B D M N\end{array}$ & $\varepsilon$ & \\
\hline 0 & $000^{\prime} 0 \angle \tau$ & $000^{\prime} 0 \angle \tau$ & $\| 0$ & 0 & 0 & 0 & 0 & $000^{\prime} 9 \varepsilon$ & $000^{\prime} 81$ & $000^{\prime} 81$ & $000^{\prime} 9 \varepsilon$ & 0 & $000^{\prime} 9 \varepsilon$ & SdO JDMN & $\tau$ & \\
\hline 0 & $000^{\prime} S \angle E$ & $000^{\prime} S L E$ & & & & & & $000^{\prime} 05$ & $000^{\prime} s z$ & $000^{\prime} s t$ & $000^{\prime} 0 \mathrm{~S}$ & & $000^{\prime} 0 S$ & 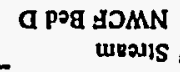 & $\underbrace{1}_{\text {\#ITR }}$ & \\
\hline & 06 & 06 & 0 & & & & & $2 I$ & 9 & 19 & 21 & & 21 & OISDM & & \\
\hline 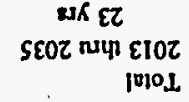 & $\begin{array}{r}2102 \text { nบy } \\
\quad 1070 \mathrm{~J}\end{array}$ & |10101| & 9102 & sloz & +102 & ع10Z & $210 \tau$ & 1102 & 0102 & 6002 & 8002 & $\angle 00 \tau$ & 9002 & 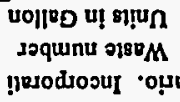 & souos & \\
\hline 2โ झ० 2 & әbed $s$ & $\cdot 0$ & 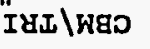 & & & oт77еx & $\theta$ & & & & & & & & & \\
\hline
\end{tabular}


Goal Scenario. Incorporating J.L. Tripp Data for 3/27/96.

Waste Volume After PEW

CBM\TRIPPGE6.XLS Page 3 of 12

\begin{tabular}{|c|c|c|c|c|c|c|c|c|c|c|c|c|c|c|c|c|c|}
\hline \multicolumn{5}{|c|}{$\begin{array}{l}\text { Waste number } 0= \\
\text { Units in Gallons }\end{array}$} & \multicolumn{2}{|l|}{ Fiscal Year } & 1996 & 1997 & 1998 & 1999 & 2000 & 2001 & \multirow[t]{2}{*}{2002} & \multirow[t]{2}{*}{2003} & \multirow[t]{2}{*}{2004} & \multirow{2}{*}{$\frac{2005}{6}$} & \multirow{2}{*}{$\begin{array}{r}2006 \\
12 \\
\end{array}$} \\
\hline & & Waste & Waste & HLLWE & E Months of $C$ & Calcination & 0[ & 11 & 7 & 5 & 12 & ] & & & & & \\
\hline & JLT & Stream & Number $F$ & Factor & \multicolumn{2}{|c|}{ Rate } & & & & & & & & & & & \\
\hline & 1 & NWCF Bed D & 0 & 12 & $244 \%$ ANN & 25000 & 0 & 50,000 & 25,000 & 0 & 50,000 & 25,000 & 0 & 0 & 0 & 25,000 & 50,000 \\
\hline & 2 & NWCF Ops & 0 & 1 & $150 \%$ ANN & Required & 0 & 33,000 & 21,000 & 15,000 & 36,000 & 3,000 & 0 & 0 & 0 & 18,000 & 36,000 \\
\hline & 3 & NWCF Turn & 2 & 1 & 2 & & 0 & 0 & 28,000 & 0 & 0 & 72,000 & 0 & 0 & 0 & 0 & 0 \\
\hline & 3 & NWCF Tum & 1 & 20 & 2 & & $\mathbf{0}$ & 0 & 2,100 & 0 & 0 & 5,400 & $\mathbf{0}$ & $\mathbf{0}$ & 0 & $\mathbf{0}$ & $\mathbf{0}$ \\
\hline & 4 & \multirow{2}{*}{ PEW Direct } & 2 & 1 & 2 & & 3,000 & 3,000 & 3,000 & 3,000 & 3,000 & 3,000 & 3,000 & 3,000 & 3,000 & 3,000 & 3,000 \\
\hline & 5 & & 1 & 30 & 2 & & 0 & 0 & 0 & 20,000 & 20,000 & 10,000 & 0 & 0 & 0 & 0 & 0 \\
\hline & 6 & 640 Decon RO & 1 & 20 & 2 & & $\mathbf{0}$ & 0 & 500 & 500 & 500 & 0 & 0 & 0 & 0 & 0 & 0 \\
\hline & 7 & Decon 601 & 1 & 20 & 2 & & 150 & 0 & 0 & $\mathbf{0}$ & 0 & 0 & 0 & $\mathbf{0}$ & 0 & 0 & 0 \\
\hline & 8 & Filter Leach & 1 & 10 & 2 & 300 & 0 & 3,450 & 3,450 & 3,450 & 3,450 & 3,450 & 3,450 & 1,740 & 420 & 1,500 & 2,580 \\
\hline & 9 & T.F. Sumps & $i$ & 1 & 1 & & 100 & 100 & 100 & 100 & 100 & 100 & 100 & 100 & 100 & 100 & 100 \\
\hline & 10 & LET\&D & 2 & 1 & 1 & & 3,500 & 0 & 0 & 0 & 0 & 0 & 0 & 0 & 0 & 0 & 0 \\
\hline & 11 & T.F. Lines & 1 & 1 & 1 & & 1,000 & 1,000 & 1,000 & 1,000 & 1,000 & 1,000 & 1,000 & 1,000 & 1,000 & 1,000 & 1,000 \\
\hline & 12 & 666 FSA deact & 2 & 30 & 2 & & 0 & 0 & 0 & 0 & 0 & 0 & 0 & 0 & 0 & 0 & 0 \\
\hline & 13 & PEW Botloms & 1 & 1 & 1 & & 0 & 0 & 0 & 0 & 0 & 0 & 0 & $\mathbf{0}$ & 0 & 0 & 0 \\
\hline & 13 & $a$ & NWCF Op & 20 & 2 & & 0 & 1,375 & 875 & 625 & 1,500 & 125 & 0 & 0 & 0 & 750 & 1,500 \\
\hline 要 & 13 & b & FAST FSA & 30 & 2 & & 833 & 833 & 833 & 833 & 833 & 833 & 833 & 833 & 833 & 833 & 833 \\
\hline & 14 & c & FAST FDP & 30 & 2 & & 100 & 100 & 100 & 100 & 100 & 100 & 100 & 100 & 100 & 100 & 100 \\
\hline & 13 & d & Cell Floor & 20 & 2 & & 1,800 & 1,800 & 1,800 & 1,800 & 1,800 & 1,800 & 1,800 & 1,800 & 1,800 & 1,800 & 1,800 \\
\hline & 13 & c & WCF Sum & 30 & 2 & & 133 & 133 & 133 & 0 & 0 & 0 & 0 & 0 & 0 & 0 & 0 \\
\hline$x$ & 13 & $\mathrm{f}$ & NWCF De & 20 & 2 & & 1,500 & 1,000 & 1,000 & 1,000 & 1,000 & 1,500 & 1,500 & 1,500 & 1,500 & 1,000 & 1,000 \\
\hline$\infty$ & 13 & $\mathrm{~g}$ & LET\&D & 10 & 2 & & 200 & 200 & 200 & 200 & 200 & 200 & 200 & 200 & 200 & 200 & 200 \\
\hline & 13 & $\mathrm{~h}$ & 603 Wet si & 30 & 2 & & 667 & 667 & 667 & 33 & 33 & 33 & 33 & 33 & 33 & 33 & 33 \\
\hline & 13 & i & 603 Dry si & 30 & 2 & & 167 & 167 & 167 & 167 & 167 & 167 & 167 & 167 & 167 & 167 & 167 \\
\hline & 13 & j & Tank Farm & 30 & 2 & & 2,000 & 2,000 & 2,000 & 2,000 & 2,000 & 2,000 & 2,000 & 2,000 & 2,000 & 2,000 & 2,000 \\
\hline & 13 & $k$ & Pilot Plant & 10 & 2 & & 100 & 100 & 100 & 100 & 100 & 100 & 100 & 100 & 100 & 100 & 100 \\
\hline & 13 & 1 & RCRA Wel & 30 & 2 & & 167 & 167 & 167 & 167 & 167 & 167 & 167 & 167 & 167 & 167 & 167 \\
\hline & 13 & $\mathbf{m}$ & Misc Bal o & 30 & 2 & & 1,000 & 1,000 & 1,000 & 1,000 & 1,000 & 1,000 & 1,000 & 1,000 & 1,000 & 1,000 & 1,000 \\
\hline & 13 & $\mathrm{n}$ & PEW Disc & 1 & 2 & & 2,000 & 2,000 & 2,000 & 2,000 & 2,000 & 2,000 & 2,000 & 2,000 & 2,000 & 2,000 & 2,000 \\
\hline & 13 & 0 & Other INE & 30 & 2 & & 2,000 & 2,000 & 2,000 & 2,000 & 2,000 & 2,000 & 2,000 & 2,000 & 2,000 & 2,000 & 2,000 \\
\hline & 14 & D\&D/Deactivat & tion Activie & 1 & 1 & & & & & & & & & & & & \\
\hline & 14 & $\mathbf{a}$ & WCF & 1 & 1 & & 0 & 0 & 0 & 0 & 0 & $\mathbf{0}$ & 0 & 0 & 0 & 0 & 0 \\
\hline & 14 & b & 603 fuel st & 10 & 2 & & 0 & 0 & 1,500 & 1,500 & 2,000 & 0 & 0 & 0 & 0 & 0 & 0 \\
\hline & 14 & $c$ & CPP-60I & 1 & 1 & & 0 & 0 & 0 & 0 & 0 & 0 & 0 & 0 & 0 & 0 & 0 \\
\hline & 14 & d & TF Heelou & 1 & 1 & & 0 & 0 & 0 & 0 & 0 & 0 & 0 & 0 & 0 & 0 & 0 \\
\hline & 14 & e & FDP & 1 & 1 & & 0 & 0 & 0 & 0 & 0 & 0 & 0 & 0 & 0 & 0 & \\
\hline & 14 & $x$ & Discretiona & $i$ & 2 Contingene & 0 & 11,765 & 11,765 & 11,765 & 11,765 & 11,765 & 11,765 & 11,765 & 11,765 & 11,765 & 11,765 & 11,765 \\
\hline & & Filters Generate & & & & & 14 & 80 & 160 & 44 & 86 & 20 & 14 & 14 & 14 & 50 & 86 \\
\hline & & Filters To Work & off & & & 316 & 330 & 295 & 340 & 269 & 240 & 145 & 44 & 0 & 0 & 0 & 0 \\
\hline & & Filters Worked & off & & & & 0 & 115 & 115 & 115 & 115 & 115 & 115 & 58 & 14 & 50 & 86 \\
\hline & & Total, gallons & & & & & 32,181 & 115,856 & 110,456 & 68,340 & 140,715 & 146,740 & 31,215 & 29,505 & 28,185 & 72,515 & 117,345 \\
\hline & & Cumulative Tot & tal, gallons & & & & 32,181 & 148,038 & 258,494 & 326,834 & 467,549 & 614,288 & 645,503 & 675,008 & 703,192 & 775,707 & 893,052 \\
\hline & & & Portion from & VCF ops & & & 0 & 84,980 & 77,360 & 15,900 & 88,160 & 105,580 & 0 & 0 & 0 & 44,080 & 88,160 \\
\hline & & & & Cumulat & ative & & 0 & 84,980 & 162,340 & 178,240 & 266,400 & 371,980 & 371,980 & 371,980 & 371,980 & 416,060 & 504,220 \\
\hline & & & Per Campaig & Ign(w/filter leach) & avg $=$ & 181260 & & & 162,340 & & & 209,640 & & & & & 162,340 \\
\hline & & & D\&D portior & on (tot less NWCF) & & & 32,181 & 30,876 & 33,096 & 52,440 & 52,555 & 41,160 & 31,215 & 29,505 & 28,185 & 28,435 & 29,185 \\
\hline & & & & Cumulat & ative & & 32,181 & 63,058 & 96,154 & 148,594 & 201,149 & 242,308 & 273,523 & 303,028 & 331,212 & 359,647 & 388,832 \\
\hline & & & & Volume to HLLWE & Eannually & & 15,817 & 69,992 & 76,592 & 40,475 & 91,850 & 130,875 & 18,350 & 16,640 & 15,320 & 41,650 & 68,480 \\
\hline & & & & Number of $3600 \mathrm{gal}$ & allon batches & & 4 & 19 & 21 & 11 & 26 & 36 & 5 & 5 & 4 & 12 & 19 \\
\hline
\end{tabular}


Goal Scenario. Incorporati Waste number

$$
\text { Waste }
$$

JLT/" Stream

1 NWCF Bed D

2 NWCF Ops

3 NWCF Tum

3 NWCF Tum

4 PEW Direct

5603 removal

6640 Decon RO

7 Decon 601

8 Filter Leach

9 T.F. Sumps

10 LET\&D

11 T.F. Lines

12 666 FSA deact

13 PEW Boltoms

赵兽

13 b

14

$13 \mathrm{~d}$

$13 \mathrm{c}$.

$13 \mathrm{f}$

$13 \mathrm{~h}$

$13 \mathrm{~h}$

$13 \mathrm{i}$

$13 \mathrm{k}$

131

$13 \mathrm{~m}$

$13 \circ$

14 D\&D/Deactiva

14 a

$14 \mathrm{~b}$

$14 \mathrm{c}$

$14 \mathrm{~d}$

14 ह

$4 \times$

\begin{tabular}{|lrrrrrr} 
& 11,765 & 11,765 & 11,765 & 11,765 & 11,765 & 11, \\
\hline Fillers Generat & 14 & 86 & 50 & 50 & 86 \\
Fillers To Wor & 0 & 0 & 0 & 0 & 0 \\
Filters Worked & 14 & 86 & 50 & 50 & 86 & \\
\hline
\end{tabular}

2007

2008

2009

$\begin{array}{lllll}0 & 50,000 & 25,000 & 25,000 & 50,000\end{array}$

$\begin{array}{lllll}0 & 36,000 & 18,000 & 18,000 & 36,000\end{array}$

$2,100 \quad 0 \quad 2,100$

$3,000 \quad 3,000 \quad 3,000$

3,000

3,000

0

$420 \quad 2,580$

100100

$\begin{array}{rr}0 & 0 \\ 1,000 & 1,000\end{array}$

$833 \quad 1,500$

$100 \quad 100$

1,800

1,500

200

33

2,000

100
167

1,000

2,000 .

$1800 \quad 100$

$\begin{array}{rr}1,000 & 1,000\end{array}$

33
167
2,000

2,000

100
167

$\begin{array}{lll}1,000 & 1,000 & 1,000 \\ 2,000 & 2,000 & 2,000 \\ 2,000 & 2,000 & 2,000\end{array}$

2,000 $\begin{array}{rrrrr}28,000 & 0 & 28,000 & 0 & 72,000\end{array}$
3,000
0

0

2,500

1,000

000
0

1,000

20,000
0

750
0

100

1,800
0

1,000
200

200
33

167
2,000

$100 \quad .100$

$167 \quad 167$

000
0

0

100
1,800
$1,000 \quad 1,000$

$\begin{array}{ll}0 & 20,000 \\ 0 & 1,500\end{array}$

$200 \quad 200$

$2,000 \quad 2,000$
$2012 \quad 2013 \quad 2014$

0
0
0
0
3,000

3,000
0

0
420

420
100

$\quad 1,000$

$1,000 \quad 1,500$

200

2,000

100
167

2,000 $\begin{array}{rr}0 & \\ 0 & \\ 0 & \\ 0 & \\ 3,000 & 3,000 \\ 0 & \\ 0 & \\ 0 & \\ 420 & 4 \\ 100 & 1 \\ 0 & \\ 1000\end{array}$

1,000

6,667

0

100

1,800

0
1,500

200

200
33
167

2,000
100
167

167
1,000

2,000

2,000
CBMITRIPPGE6.XIS Page 4 of 12

2015

\begin{tabular}{|lll} 
& Total & Total \\
Total & Thru 2012 & 2013
\end{tabular}

\begin{tabular}{l|llll} 
& Total & & Thrs 2012 & 2013 thru 2035 \\
& & & & $23 \mathrm{yrs}$
\end{tabular}

$375,000 \quad 375,000$

$270,000 \quad 270,000$

$228,000 \quad 228,000$

$17,100 \quad 17,100$

$50,000 \quad 50,000$

0,000

150

35,940

1,700

3,500

17,000

100,000

11,250

11,250

1,700

30,600

400
20,500

3,400

2,467

2,833

34,000

1,700

2,833

17,000

34,000

34,000

42,000

0
$\mathbf{0}$

5,000

5,000

5,000
0

0
0

11,765

247,059

200,000

$\begin{array}{rr}0 & 0 \\ 11,765 \quad 11,765\end{array}$

11,765

14
0
14

14
0

$8,285 \quad 136,511 \quad 121,78$

$91,681 \quad 213,911 \quad 47,35$

$\begin{array}{lllllll}951,336 & 1,087,848 & 1,209,629 & 1,301,311 & 1,515,222 & 1,562,573\end{array}$

34,018

34,018

27,351

27,351
$1,623,943$

27,351

$1,651,294$

27,351

$1,678,645$

$1,562,573$

$906,300 \quad 906,300$

$\begin{array}{rrrr} & 696,660 & 740,740 & 906,300 \\ & 162,340 & 209,640\end{array}$

$906,300 \quad 000$

906,300

906,300

906,300

906,300

\begin{tabular}{rrrrrrrrrr}
28,185 & 48,351 & 47,601 & 47,601 & 48,351 & 47,351 & 34,018 & 27,351 & 27,351 & 27,351 \\
417,016 & 465,368 & 512,969 & 560,571 & 608,922 & 656,273 & 690,291 & 717,643 & 744,994 & 772,345 \\
\hline 45,420 & 87,64 & 90,917 & 60,81 & 165,047 & 34,467 & 21,153 & 14,487 & 14,487 & 14,487
\end{tabular}

$\begin{array}{rrrrrr}45,420 & 87,647 & 90,917 & 60,817 & 165,047 & 34,487\end{array}$

$21,153 \quad 14,487$

$4,487 \quad 14,487$

$1,134,987$

$$
\begin{array}{r}
0 \\
0 \\
0 \\
0 \\
69,000 \\
0 \\
0 \\
0 \\
9,660 \\
2,300 \\
0 \\
23,000 \\
0 \\
0 \\
0 \\
0 \\
2,300 \\
41,400 \\
0 \\
34,500 \\
4,600 \\
767 \\
3,833 \\
46,000 \\
2,300 \\
3,833 \\
23,000 \\
46,000 \\
46,000 \\
0
\end{array}
$$

9,000
0

2,300

3,833
23,000

10

.

4

315 
Goal Scenario. Incorporating J.L. Tripp Data for 3/27/96

type; 2 = non-sodium-acid-decon(H+) waste type.

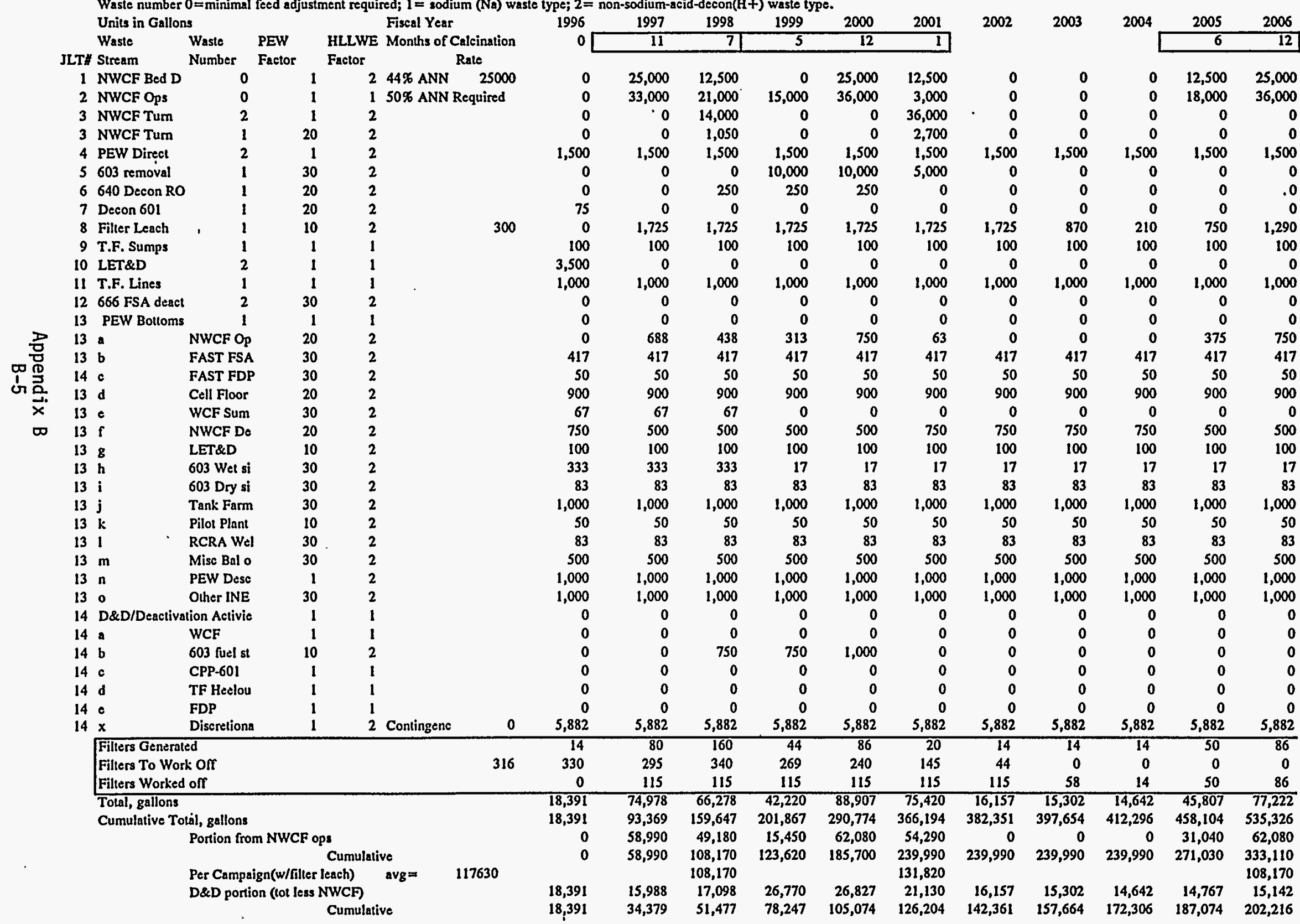


Waste Volume After HLLWE

Goal Scenario. Incorporali Wasto n Units in Gallon Waste

JLT" Stream

1 NWCF Bed D

2 NWCF Ops

3 NWCF Tum

3 NWCF Tum

4 PEW Direct

6640 Decon Ro

7 Decon 601

8 Filter Leach

9 T.F. Sumps

10 LET\&D

11 T.F. Lines

12666 FSA deact

$\rightarrow \quad 13$ PEW Bottoms

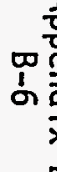

13 a

$14 \mathrm{c}$

$13 \mathrm{~d}$

$\times 13 \circ$

$\infty \quad 13 \mathrm{f}$

138

$13 \mathrm{~h}$

$13 \mathrm{i}$

$13 \mathrm{j}$

$13 \mathrm{k}$

131

$13 \mathrm{~m}$

$13 \mathrm{n}$

14 D\&D/Deactiva

14 a

14 b

14.

$14 \mathrm{~d}$

$14 \mathrm{e}$

$14 \times$

Fillers Generat

Fillers To Wo Fillers Worked Total, gallons

Cumulative Tot
2007

\begin{tabular}{|rr|rr|}
\hline 2008 & 2009 & 2010 & 2011 \\
\hline 12 & 6 & 6 & 12 \\
\hline
\end{tabular}

2012

$\begin{array}{rrrrr}0 & 25,000 & 12,500 & 12,500 & 25,000 \\ 0 & 36,000 & 18,000 & 18,000 & 36,000 \\ 14,000 & 0 & 14,000 & 0 & 36,000 \\ 1,050 & 0 & 1,050 & 0 & 2,700\end{array}$

$\begin{array}{rrrrr}1,050 & 0 & 1,050 & 0 & 2,700 \\ 1,500 & 1,500 & 1,500 & 1,500 & 1,500\end{array}$

0
0

0

0
210

100
0

1,000

0

0
0
0

$0 \quad 750$

900

0

750
100

100
17

83
1,000

1,000

50
83

50
83
500
000

$\begin{array}{rr}1,000 & 1,000 \\ 0 & 0\end{array}$

$0 \quad 0$

100

0
1,500

0
1,290
100

$\begin{array}{rrrr}0 & 0 & 100 & 100\end{array}$

$\begin{array}{rrrr}1,000 & 1,000 & 1,000 & 1,000 \\ & 10,000 & 10,000 & 10,000\end{array}$

$\begin{array}{rrrr}0 & 0 & 0 & 0\end{array}$

$\begin{array}{rrr}0 & 0 & 0 \\ 50 & 50 & 50\end{array}$

$900 \quad 900 \quad 900$

$\begin{array}{rrr}0 & 0 & 900 \\ 500 & 500 & 500\end{array}$

$500 \quad 500$

$\begin{array}{rrrr}83 & 83 & 17 & 17 \\ 173 & 83\end{array}$

$\begin{array}{lrr}50 & 50 & 1,000\end{array}$

$83 \quad 83$

500

$\begin{array}{rr}500 & 500 \\ 1,000 & 1,000\end{array}$

$\begin{array}{lll}1,000 & 1,000 \quad 1,000\end{array}$
$100 \quad 750$

$\begin{array}{rrrrr}5,882 & 5,882 & 5,882 & 5,882 & 5,882\end{array}$

0
$582 \quad 5,882$

$\begin{array}{rrrrrrr}0 & 0 & 0 & 0 & 0 & 0 & 0 \\ 14 & 86 & 50 & 50 & 86 & 14 & 14 .\end{array}$

\begin{tabular}{rrrrrrrrrr}
29,692 & 86,806 & 70,441 & 55,391 & 125,506 & 24,226 & 17,559 & 14,226 & 14,226 & 14,226 \\
565,018 & 651,824 & 722,265 & 777,655 & 903,161 & 927,387 & 944,946 & 959,171 & 973,397 & 987,623 \\
15,050 & 62,080 & 46,090 & 31,040 & 100,780 & 0 & 0 & 0 & 0 & 0 \\
348,160 & 410,240 & 456,330 & 487,370 & 588,150 & 588,150 & 588,150 & 588,150 & 588,150 & 588,150 \\
& & 108,170 & & 131,820 & & & & \\
14,642 & 24,726 & 24,351 & 24,351 & 24,726 & 24,226 & 17,559 & 14,226 & 14,226 & 14,226 \\
216,858 & 241,584 & 265,935 & 290,285 & 315,011 & 339,237 & 356,796 & 371,021 & 385,247 & 399,473 \\
& & & & \multicolumn{5}{c}{ Average vol reduction thru HLLWE } &
\end{tabular}

Average vol reduction Overall

CBM ITRIPPGE6.XLS Page 6 of 12

Total Total

\begin{tabular}{rlll}
2016 & Total & \multicolumn{3}{c}{ Thru 2012} & 2013 thru 2035 \\
0 & 21 & 17 & $23 \mathrm{yrs}$
\end{tabular}

0

$\begin{array}{lll}187,500 & 187,500 & 0 \\ 270,000 & 270,000\end{array}$

$114,000 \quad 114,000$

$\begin{array}{rrr}1,500 & 1,500 & 1,500 \\ 0 & 0 & 0\end{array}$

\begin{tabular}{r|rrr}
0 & 8,550 & 8,550 & \\
1,500 & 31,500 & 25,500 & 34,500
\end{tabular}

0. $\begin{array}{rrr}-25,000 & 25,000 & 0\end{array}$

\begin{tabular}{r|rrr}
0 & 750 & 750 & \\
0 & 75 & 75 & 0 \\
210 & 18,810 & 17,970 & 4,830
\end{tabular}

$\begin{array}{rrrr}-100 & 2,100 & 1,700 & 2,300 \\ 0 & 3,500 & 3,500 & \end{array}$

$1,000 \quad 21,000 \quad 17,000 \quad 23,000$

$\begin{array}{rrrr}0: & 53,333 & 50,000 & 0 \\ 0 & 0 & 0 & 0\end{array}$

$\begin{array}{rrrr}0 & 0 & 0 & 0 \\ 0 & 5,625 & 5,625 & 0 \\ 50 & 5,000 & 5,000 & 0\end{array}$

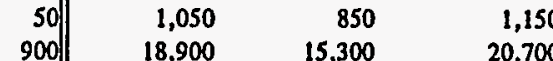

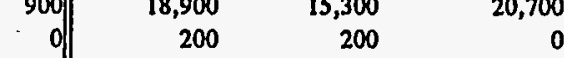

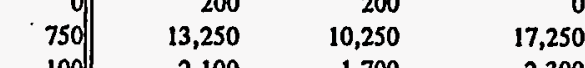

\begin{tabular}{r|rrr}
100 & 2,100 & 1,700 & 2,300 \\
17 & 1,300 & 1,233 & 383 \\
83 & 1,750 & 1,417 & 1,917
\end{tabular}

$\begin{array}{rrrr}1,000 & 21,000 & 17,000 & 1,917\end{array}$

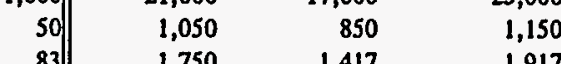

$\begin{array}{rrrr}83 & 1,750 & 1,417 & 1,917 \\ 500 & 10,500 & 8,500 & 11,500\end{array}$

$\begin{array}{llll}1,000 & 21,000 & 17,000 & 23,000 \\ 1,000 & 21,000 & 17,000 & 23,000\end{array}$

$\begin{array}{cccc}0 & 0 & 0 \\ 0 & 0 & 0 & 0\end{array}$

$2,500 \quad 2,500$

$0 \quad 0$

$\begin{array}{rrr}0 & 0 & 0 \\ 0 & 100,000 & 0\end{array}$

\begin{tabular}{lll}
14 & 135,294 \\
\hline 987,623 & 927,387 & 327,191
\end{tabular}

$987,623 \quad 927,387 \quad 327,191$

$588,150 \quad 588,150$

$\begin{array}{ll}588,150 & 588,150 \\ 399,473 & 339,237\end{array}$

$399,473 \quad 339,237$

1.68 


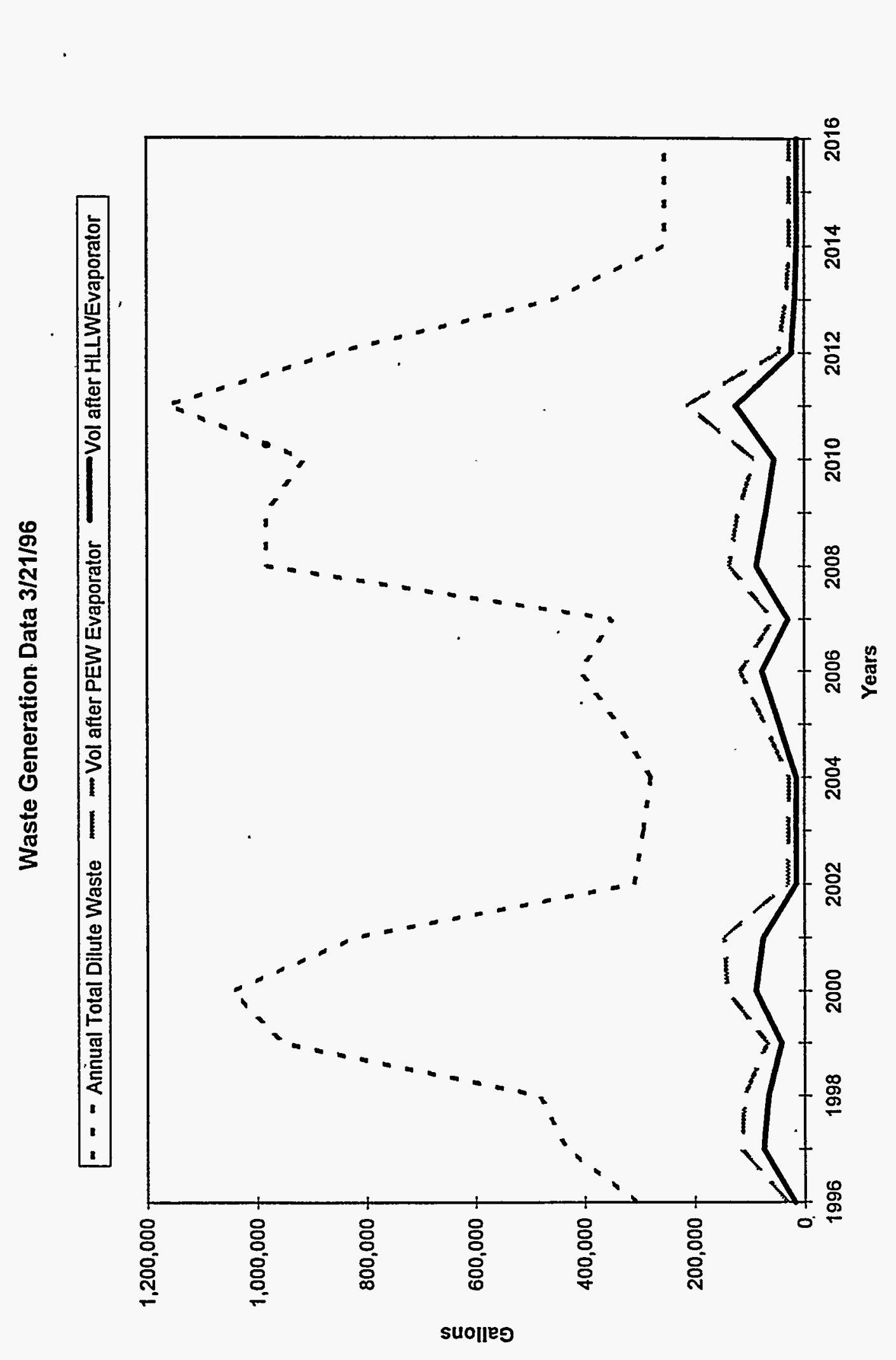

疋

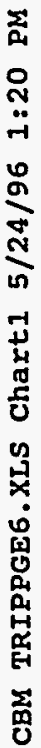

Appendix B

B-7 


\section{Cumulative Waste Generation Data 3/21/96}

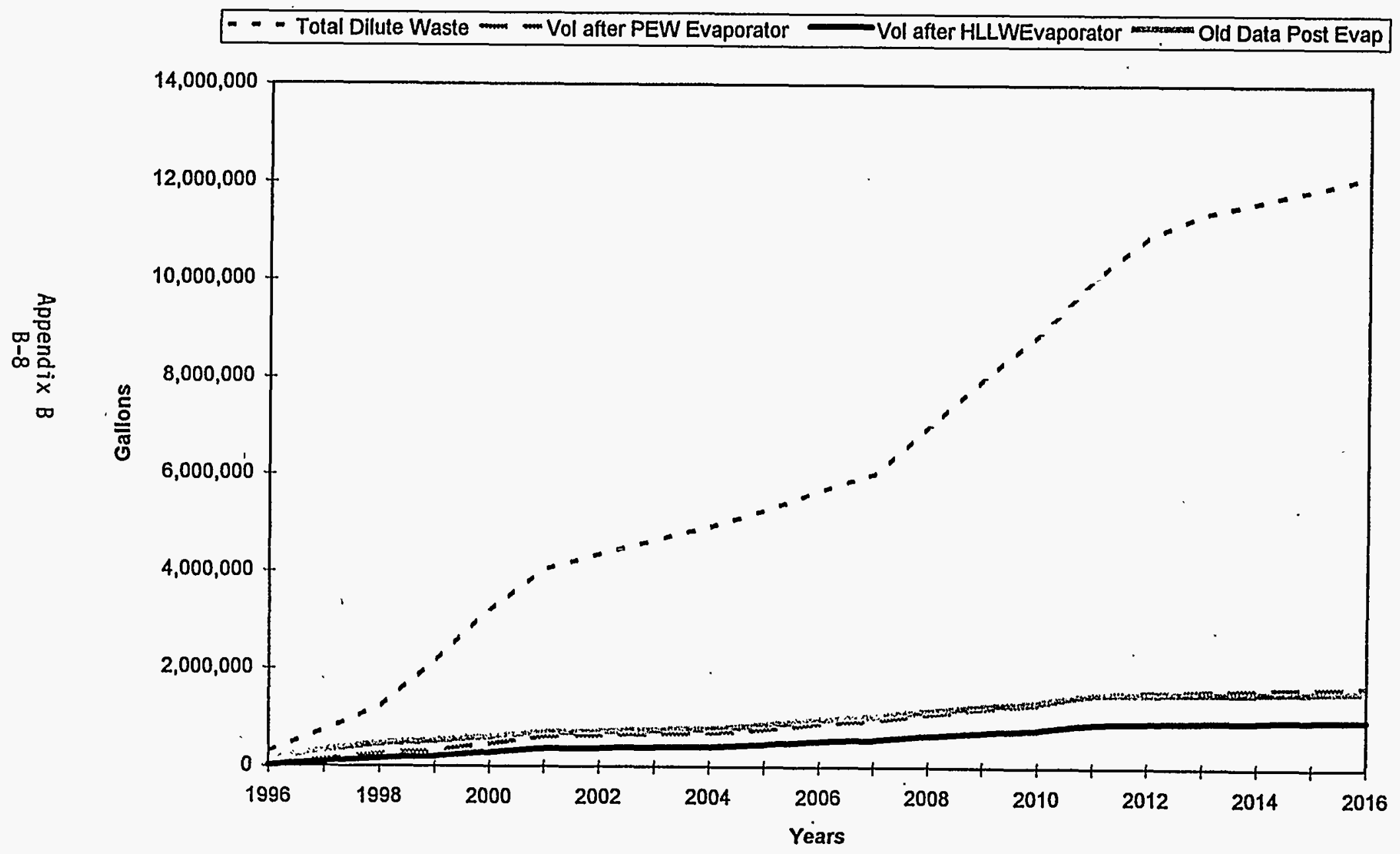




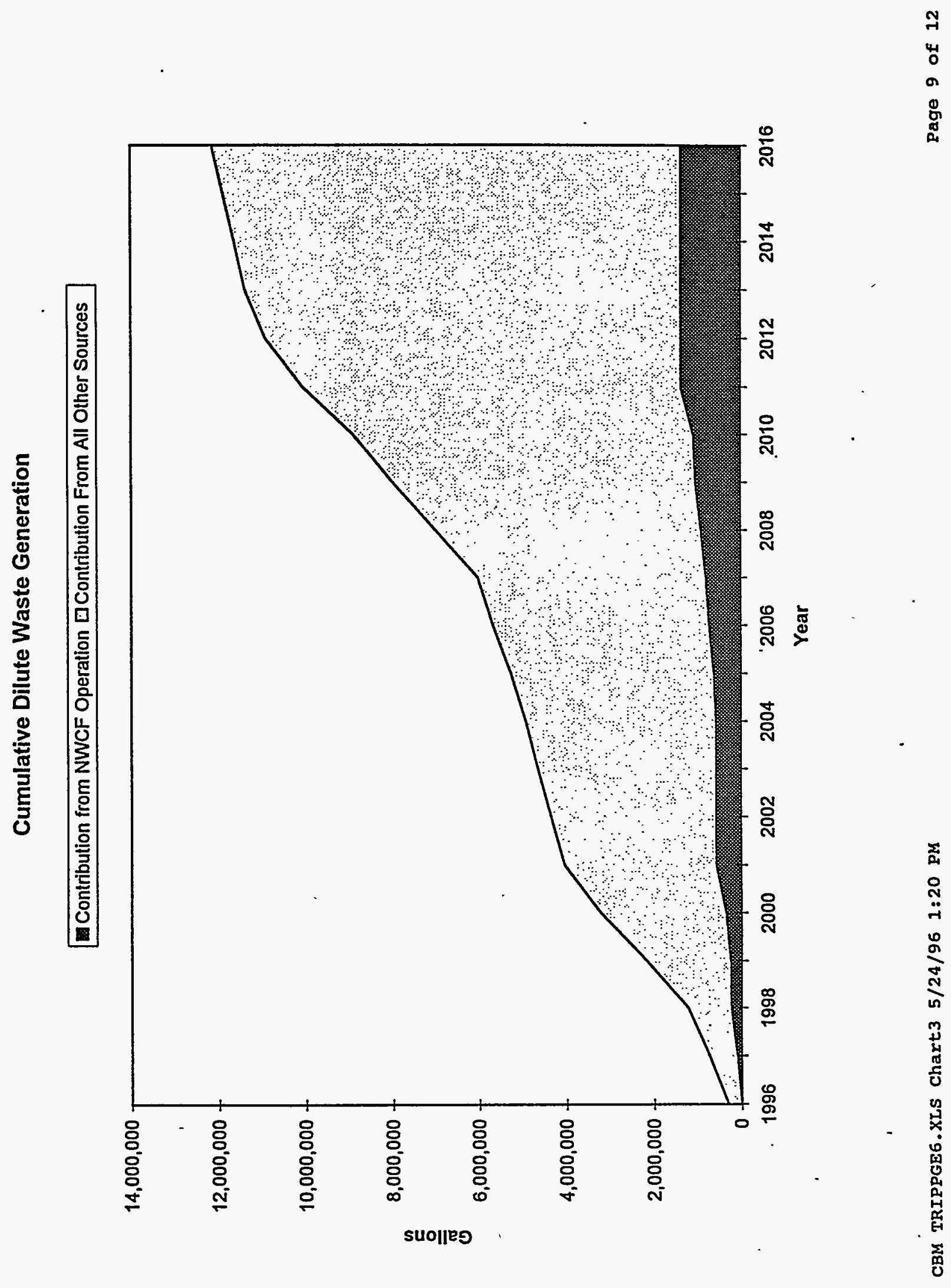

Appendix B

B-9 


\section{Cumulative Volumes After PEW Evaporator}

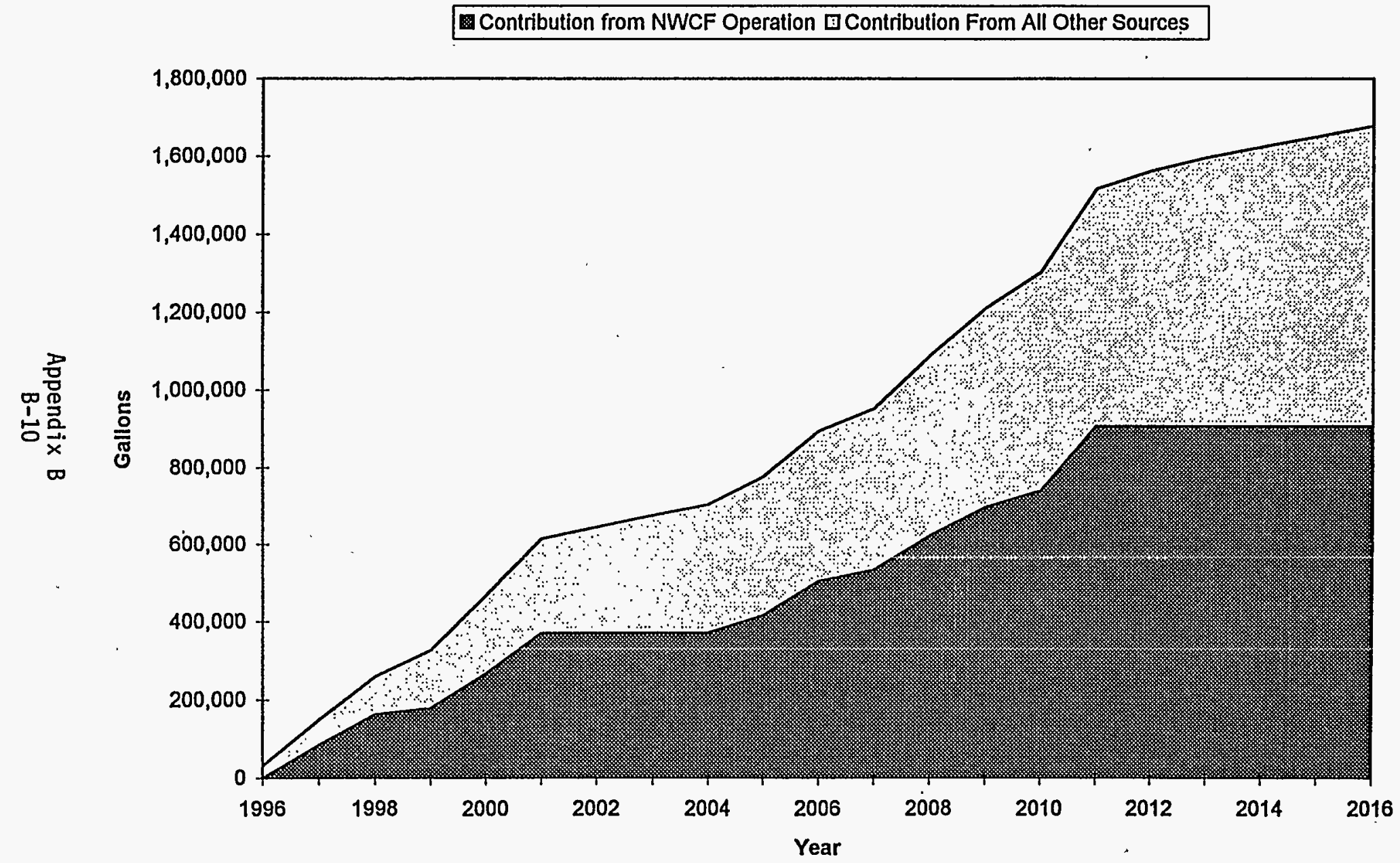




\section{Cumulative Volumes After HLLWEvaporator}

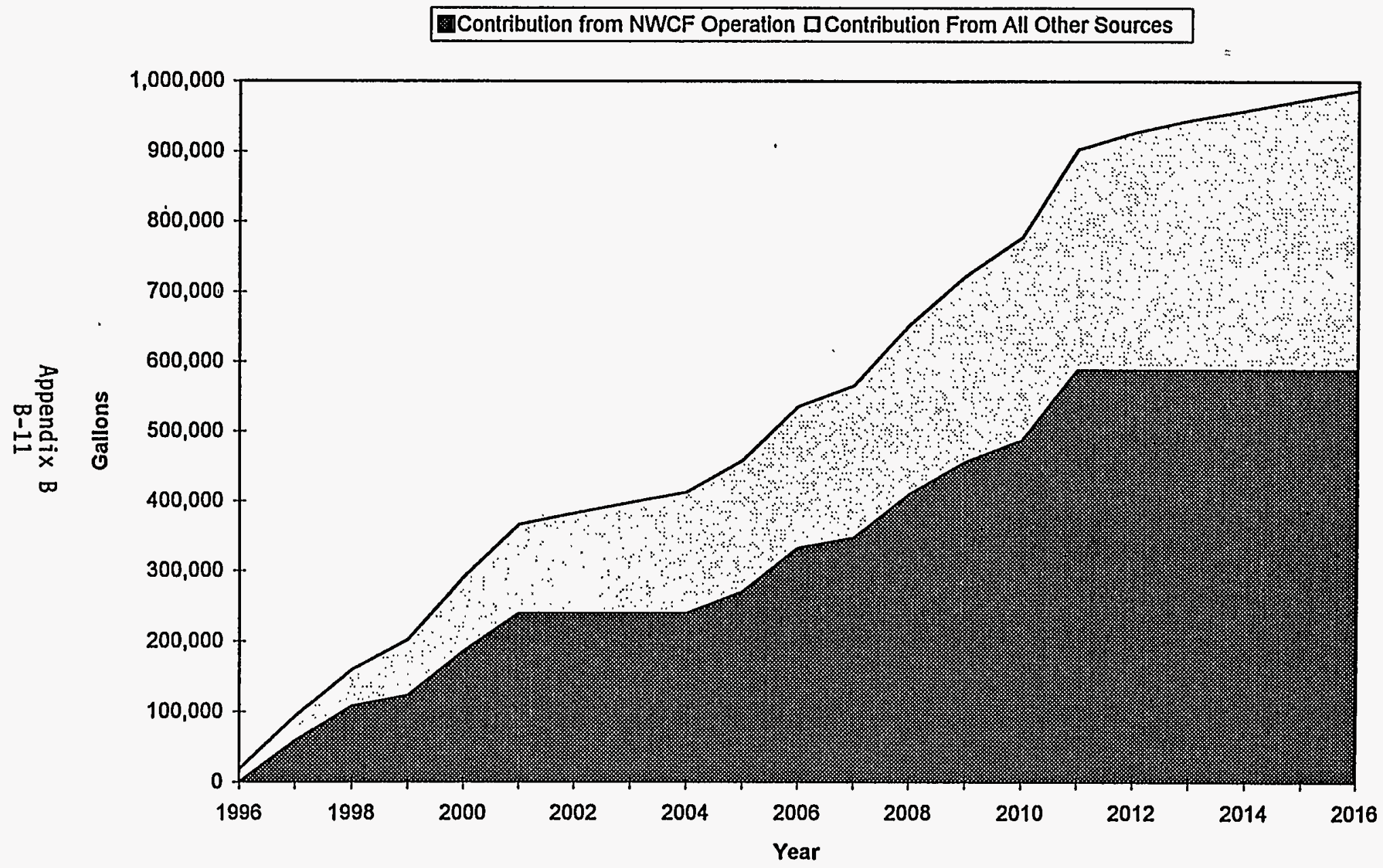




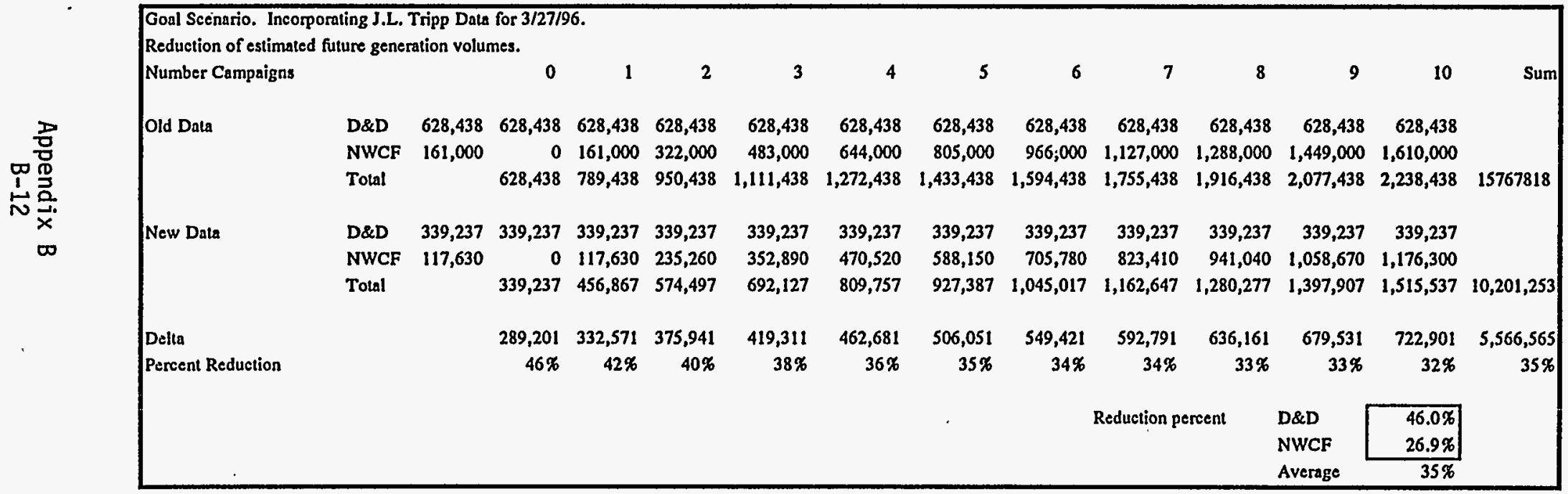




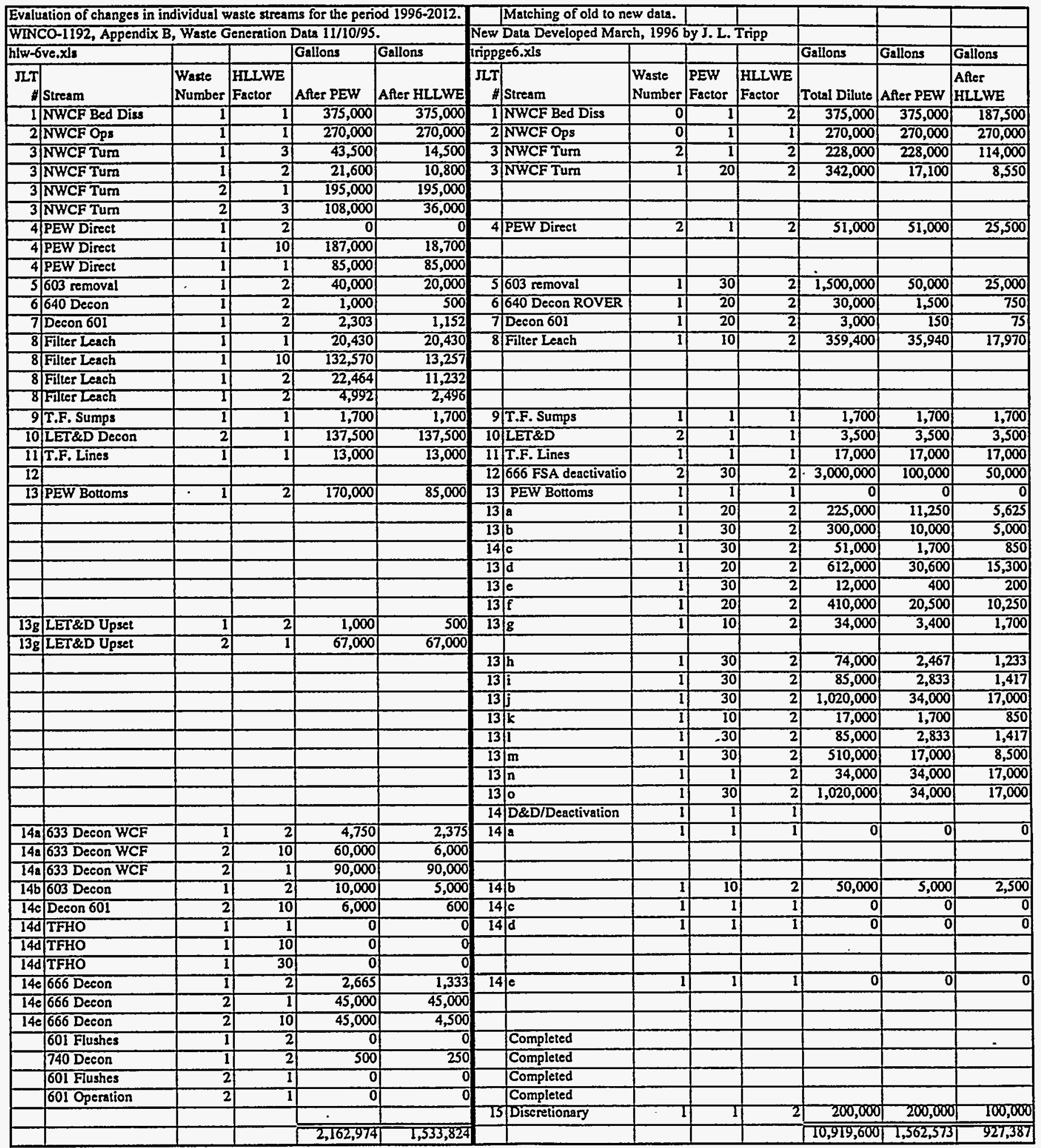




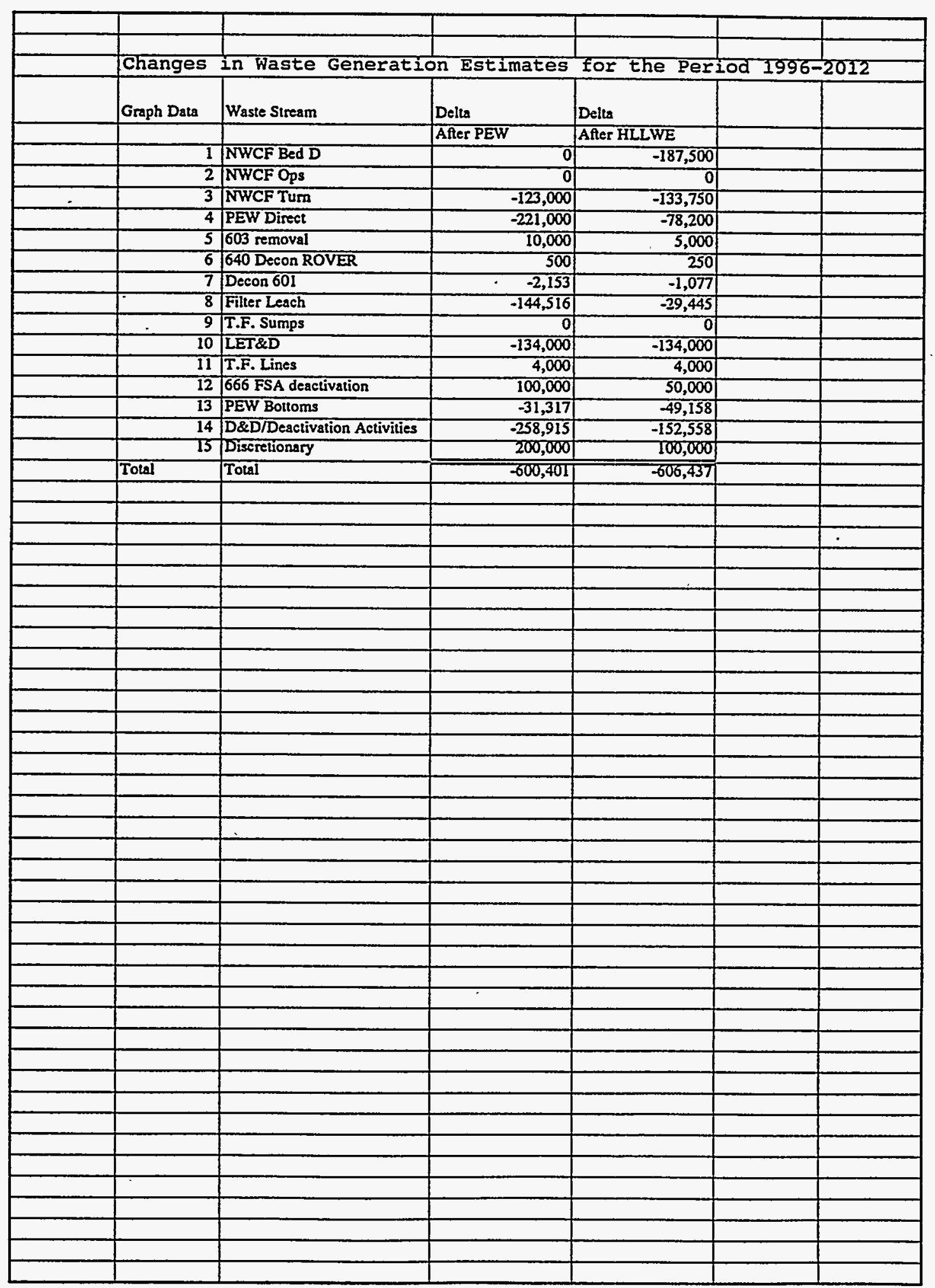

Appendix B

B-14 